\title{
One Century of Study: What We Learned about Paracoccidioides and How This Pathogen Contributed to Advances in Antifungal Therapy
}

\author{
Erika Seki Kioshima ${ }^{1, *}$, Patrícia de Souza Bonfim de Mendonça ${ }^{1}$, Marcus de Melo Teixeira ${ }^{2}$, \\ Isis Regina Grenier Capoci ${ }^{1}$, André Amaral ${ }^{3} \mathbb{D}$, Franciele Abigail Vilugron Rodrigues-Vendramini ${ }^{1}$, \\ Bruna Lauton Simões ${ }^{1}$, Ana Karina Rodrigues Abadio ${ }^{4}$, Larissa Fernandes Matos ${ }^{5,6}$ and \\ Maria Sueli Soares Felipe ${ }^{7}$
}

check for

updates

Citation: Seki Kioshima, E.; de Souza Bonfim de Mendonça, P.; de Melo Teixeira, M.; Grenier Capoci, I.R.;

Amaral, A.; Vilugron

Rodrigues-Vendramini, F.A.; Lauton Simões, B.; Rodrigues Abadio, A.K.; Fernandes Matos, L.; Soares Felipe, M.S. One Century of Study: What We Learned about Paracoccidioides and How This Pathogen Contributed to Advances in Antifungal Therapy. J Fungi 2021, 7, 106. https://doi.org/ 10.3390/jof7020106

Academic Editors: Maria José Soares Mendes Giannini, Ana Marisa Fusco Almeida and Gil Benard

Received: 10 December 2020

Accepted: 26 January 2021

Published: 2 February 2021

Publisher's Note: MDPI stays neutral with regard to jurisdictional claims in published maps and institutional affiliations.

Copyright: (C) 2021 by the authors Licensee MDPI, Basel, Switzerland. This article is an open access article distributed under the terms and conditions of the Creative Commons Attribution (CC BY) license (https:// creativecommons.org/licenses/by/ $4.0 /)$
1 Program in Biosciences and Pathophysiology, Department of Clinical Analysis and Biomedicine, State University of Maringa (UEM), Maringa, Parana 87020-900, Brazil; patbonfim.09@gmail.com (P.d.S.B.d.M.); isiscapoci@gmail.com (I.R.G.C.); francieleavr@gmail.com (F.A.V.R.-V.); blautons@gmail.com (B.L.S.)

2 Faculty of Medicine, University of Brasília (UnB), Brasilia, Distrito Federal 70910-900, Brazil; marcus.teixeira@gmail.com

3 Institute of Tropical Pathology and Public Health, Federal University of Goiás, Goiânia 74690-900, Brazil; amaral.nanobio@gmail.com

4 Faculty of Agricultural Social Sciences, Mato Grosso State University, Nova Mutum, Mato Grosso 78450-000, Brazil; anakarina.abadio@gmail.com

5 Faculty of Ceilandia, University of Brasília (UnB), Brasília, Distrito Federal 72220-275, Brazil; lfernandesmatos@gmail.com

6 Program in Microbial Biology, Institute of Biological Sciences, University of Brasília, Brasília 70910-900, Brazil

7 Program of Genomic Sciences and Biotechnology, Catholic University of Brasilia, Brasília 70790-160, Brazil; msueli@ucb.br

* Correspondence: eskcotica@uem.br; Tel.: +55-44-3011-4810

Abstract: Paracoccidioidomycosis (PCM) is a notable fungal infection restricted to Latin America. Since the first description of the disease by Lutz up to the present day, Brazilian researchers have contributed to the understanding of the life cycle of this pathogen and provided the possibility of new targets for antifungal therapy based on the structural and functional genomics of Paracoccidioides. In this context, in silico approaches have selected molecules that act on specific targets, such as the thioredoxin system, with promising antifungal activity against Paracoccidioides. Some of these are already in advanced development stages. In addition, the application of nanostructured systems has addressed issues related to the high toxicity of conventional PCM therapy. Thus, the contribution of molecular biology and biotechnology to the advances achieved is unquestionable. However, it is still necessary to transcend the boundaries of synthetic chemistry, pharmaco-technics, and pharmacodynamics, aiming to turn promising molecules into newly available drugs for the treatment of fungal diseases.

Keywords: genomic; new species discovery; new targets; antifungal

\section{From the First Description of the Disease to Functional Genomics-112 Years of Gathered Knowledge. A Brazilian Middle West Perspective}

First described in 1908 by Adolpho Lutz as "A Pseudococcidic Mycosis Localized in the Mouth and Observed in Brazil" [1], paracoccidioidomycosis is the most prevalent systemic mycosis in South America. This fungal disease was named Brazilian blastomycosis, South American blastomycosis, paracoccidioidal granuloma, Lutz or Lutz-Splendore-Almeida disease but only in 1971 was it officially named paracoccidioidomycosis after a meeting of medical mycologists in Medellin, Colombia [2]. PCM was confused with coccidioidomycosis for about two decades. However, after a precise microbiological characterization of 
the dimorphic and multi-budding nature of the fungus, the disease was ranked as a new mycosis by identifying its etiological agent as Paracoccidioides brasiliensis [3]. Historically, the disease has been extensively investigated in the Brazilian Southeast, Colombia and Venezuela regarding the etiological agent, epidemiological characteristics, disease variation, immunological aspects, cell wall components, diagnostics and treatment, as well as the biological aspects of this saprophytic fungus.

PCM primarily affects the lungs upon the inhalation of airborne infectious propagules named conidia. These cells produced during the filamentous phase of the fungus are dislodged and aerosolized after soil perturbation. Most natural infections are asymptomatic and characterized by a self-resolved disease in humans and other mammalian hosts [4]. Inside the host lungs, the fungus switches its morphology to multi-budding yeast cells, triggering the infection and leading to an acute/subacute disease (also known as the juvenile form) predominantly reported in infants/adolescents, or into a chronic-to-disseminated polymorphic disease. A detailed review can be found at Shikanai-Yasuda et al., 2017 [5].

Past relevant studies carried out by Willian Barbosa, comparing clinical PCM in different parts of Brazil, suggested that lymphatic-abdominal forms of Paracoccidioides were predominant among patients in Midwestern, especially in Goiás state, compared to Southeastern states [6,7]. The Brazilian Midwest is composed of the Federal District and Goiás, Mato Grosso and Mato Grosso do Sul states, harboring two predominant ecosystems (Brazilian Savanna and Pantanal) and is a key ecological area of transition to the Amazon. These observations drove several research groups to investigate local clinical and microbiological determinants of PCM in Brazil. It is worth noting that in the last three decades, there has been massive deforestation of the Brazilian savanna and Amazon landscapes in Brazil and surrounding countries due to agricultural practices and pasture [8,9]. Consequently, PCM cases increased in those areas, redrawing the epidemiological map of this fungal disease. A discussion of this topic can be found in Martinez, 2017 [8]. Notably, those patients from Goiás, Mato Grosso and Rondônia (Midwestern Brazil) had apparent clinical symptomatology of PCM and microbiological features of Paracoccidioides, but a high percentage of negative serological tests was observed by utilizing the well-characterized Pb339 antigen obtained from a strain isolated in São Paulo (Southeast) [10-12]. An antigenic preparation using a local strain, named 510B, was proposed and was crucial to improving antibody detection assays in Midwestern Brazil [12].

Although studies had already indicated a high degree of genetic divergence among isolates of $P$. brasiliensis, at that moment there was no geographical correlation with these findings [13-15]. By Random Amplification of Polymorphic DNA (RAPD) markers, MolinariMadlum et al. [13] were able to identify two groups with different virulence degree and a high of genetic diversity. Despite the study focusing on the analysis of genetic markers related to virulence, the $\mathrm{Pb} 01$ isolate already presented a different pattern to well-known P. brasiliensis isolates, such as Pb18 [13]. The RAPD studies continued to show high genetic variability among clinical isolates, including atypical forms [14]. Next, Hahn et al. [15] reported the same observations comparing the RAPD profiles of Mato Grosso and other areas of the disease range in Brazil. The genetic variability was characterized, but it was not possible to establish a geographical differentiation pattern [15]. Thus, despite the suspicions of clinicians, who had already observed in practice that $P$. brasiliensis isolates from the Midwestern were different, confirmation was only possible later with advances in fungal genotyping methods.

At the beginning of the 2000s, fungal systematics and taxonomy dramatically changed when the phylogenetic species concept (PSC) was implemented, which relied on the phylogenetic concordance of several loci in a given population $[16,17]$. PSC was used to delineate phylogenetic species with Histoplasma sp., Coccidioides sp., and at least three phylogenetic species diagnosed with P. brasiliensis: S1 - widely distributed in Latin America; PS2-less abundant and prevalent in southeastern Brazil and Venezuela; and PS3 and PS4-restricted to Colombia and Venezuela respectively [18]. These authors did not 
include any isolates from the Brazilian Midwest. Another set of strains were investigated in parallel by other groups, and it was observed that the Pb01 strain did not cluster in any P. brasiliensis phylogenetic species reported at that time [19]. The isolation and microbiological characterization of the Paracoccidioides $\mathrm{Pb} 01$ strain were carried out at the Instituto de Patologia Tropical e Saúde Pública, Federal University of Goiás (IPTSP-UFG) by Dr. Maria do Rosário at the beginning of the 1990s. Since this strain was collected in Goiás and presented a unique intron insertion at the hsp70 gene [20], researchers screened the genetic background of 54 strains from Midwestern Brazil, aiming to find the shared genomic patterns [21]. Seventeen isolates from Mato Grosso, Goiás and a single occurrence in Ecuador were found to carry the same genomic insertion compared to the Pb01 strain, and these were named "Pb01-like" [21]. It was found that the Pb01-like strains were phylogenetically distinct from the P. brasiliensis species complex using PSC. These authors also demonstrated that conidial cells from strains belonging to the "Pb01-like" group were morphologically longer than the barrel-shaped P. brasiliensis conidia. This key finding led to the proposal of a new species comprising the Pb01-like population and this was named Paracoccidioides lutzii as an honor to the disease's discoverer, Adolpho Lutz [22]. These observations were vital to understanding and explaining the serological immunodiagnostic challenges in PCM patients from Midwestern Brazil infected by P. lutzii, which sometimes was mis-diagnosed as tuberculosis. In the same fashion, the three other phylogenetic species within P. brasiliensis strictu sensu were proposed as follows: P. americana (PS2), $P$. restrepiensis (PS3) and P. venezuelensis (PS4) [23].

Through an initiative of the Broad Institute and several researchers, the reference genome of three species of Paracoccidioides were sequenced using Sanger Technology: Pb18 (P. brasiliensis), $\mathrm{Pb} 03$ (P. americana) and $\mathrm{Pb} 01$ (P. lutzii). The structural genomes ranged in size from $29.1 \mathrm{Mb}$ to $32.9 \mathrm{Mb}$ and encoded 7610 to 8130 genes. The comparative genomics of members of the Onygenales order contributed to understanding the clinical, biological and genetic differences among the species of Paracoccidioides. They also allowed phylogenetic studies to be carried out that estimated the divergence of this genus from other dimorphic fungi. This work provided, furthermore, a collection of unique genes and metabolic pathways conserved among Paracoccidioides dimorphic relatives [24]. More recently, the genome of 77 strains representing the five species of Paracoccidioides was sequenced using short-read Illumina technology and used for evolutionary analysis. The results reinforced that all Paracoccidioides species are reciprocally monophyletic, and gene flow (or hybridization) between species is infrequent $[25,26]$. Today, five structural draft genomes of Paracoccidioides isolates ( $\mathrm{Pb} 18, \mathrm{~Pb} 03, \mathrm{~Pb} 01, \mathrm{PbCnh}$ and $\mathrm{Pb} 300)$ have been sequenced, assembled, annotated and deposited in genomic databases. To improve and standardize the current genomic functional annotation, the Paracoccidioides genomic database (ParaDB, http://Paracoccidioides.com/) was recently launched, in which all data were compiled and manually curated, and can now be accessed for any in silico analysis. The availability of this resource will undoubtedly facilitate post-genomic studies of the Paracoccidioides $[27,28]$.

From the 1990s, molecular studies aiming to explore the biology of Paracoccidioides had begun, even before the deduction of the full genomes. In 1995, Goldani et al. [29] cloned and sequenced the first genomic fragment related to a surface glycoprotein from P. brasiliensis for diagnostic purposes and differentiation of $P$. brasiliensis clinical isolates. In the following year, the gene encoding the $43 \mathrm{kDa}$ glycoprotein (gp43) was characterized and cloned [30]. Historically it is important to note that, this immunodominant antigen of $P$. brasiliensis found in patients with PCM, was first described by Yarzabal L et al., as band E [31]. Later, this band was elegantly characterized by Dr. Travassos' group, as the gp43 antigen. In the following decade, a significant advance in the understanding of Paracoccidioides sp. biology took place. Many studies have explored at the proteomic and genomic levels the differences between the two forms of the fungus, the infective (mycelial and saprophytic) and the pathogenic (yeast), as well as the morphogenetic events that culminate in the temperaturedependent dimorphic transition. Salem-Izaac et al. [32] identified more homogeneous protein synthesis patterns and gene expression in yeast cells than in the mycelial phase after 
evaluating several P. brasiliensis isolates. Through two-dimensional protein electrophoresis, Cunha et al. [33] identified and characterized differentially expressed proteins from each dimorphic stage of the fungus ( $\mathrm{Pb} 01$ ); among them, $\mathrm{PbM} 46$, an enolase-like protein, was very abundant in the mycelium while PbY20 was only found in the yeast phase, which later was identified as a member of the flavodoxin-like WrbA family [34]. In parallel, Venâncio et al. [35] identified about 20 differentially expressed genes between $P$. brasiliensis yeast and mycelium cells and three regulated cDNAs during the transition from the infective to the pathogenic phase by using the differential display (DD) approach.

By in silico electronic subtraction, the expressed sequence tag (EST) sequencing project was started in 2001. Researchers characterized the functional genome of the Paracoccidioides $\mathrm{Pb} 01$ isolate, actually known as P. lutzii. The project resulted in the sequencing of 6022 genes differentially expressed between the forms of mycelium and yeast, and boosted the understanding of the metabolic and molecular events that Pb01 induces in its lifecycle, which enable it to adapt to the conditions found in the natural environment as a saprophytic form or in the host in its pathogenic phase. This study also provided categorized and comprehensive data related to cell cycle, stress responses machinery, signal transduction pathways, virulence genes, and drug targets for this pathogen [36-39].

At the same time, by EST sequencing, researchers from southeastern Brazil (São Paulo state) started the transcriptomic characterization of isolate $\mathrm{Pb} 18$, which is a P. brasiliensis stricto sensu individual. By sequencing 4692 expressed genes and comparative analysis with the Candida albicans database, these authors pinpointed potential homologues of $P$. brasiliensis essential for virulence and pathogenicity [40]. Among preferentially expressed yeast genes, some were required for metabolism, signal transduction pathways, growth and morphogenesis, and sulfur metabolism [41].

The abundant data generated by the functional genome projects of $P$. brasiliensis and P. lutzii (at that time it had not yet been defined as the P. lutzii species) were pivotal for further studies exploring the molecular mechanisms developed during the temperaturedependent dimorphic transition of these fungi, which is considered the main morphogenetic event required for the establishment of the disease [42,43]. Aiming to take the next step in understanding the metabolic adaptation of P. lutzii within the host, Tavares et al. [44] evaluated the gene expression of yeast cells after six hours of interaction with peritoneal murine macrophages. From 1152 genes evaluated by cDNA microarray technology, 152 genes were differentially transcribed in this condition. The collected data show that the fungus ( $\mathrm{Pb01}$ ) has a strong capacity to adapt to the harsh phagocyte environment, modulating the genes required for glucose and amino acid assimilation/production, cell wall remodeling, and oxidative stress response to evade and counteract the immune system. This plasticity guarantees its survival and continuation in the host.

Bailão et al. [45] identified by cDNA Representational Difference Analysis (cDNARDA) several genes required by yeast cells for dissemination via the hematogenic route. Among these, genes related to copper and iron metabolism were found, in addition to those necessary for cell wall/membrane remodeling. Next, Bailão et al. [46], when exposing $\mathrm{Pb} 01$ yeasts cells to blood and plasma, also observed changes of the transcriptional profile response to these conditions that would mimic the host environment. Other studies prompted a greater understanding of the survival and adaptation of Paracoccidioides in different sites and environments encountered inside the host $[47,48]$.

Amid the progress made by transcriptomes, the genetic manipulation of Paracoccidioides was still something to be mastered. Two studies were published, the first in 2004. Here, Leal et al. [49] describe the technique of genetic transformation, mediated by Agrobacterium tumefaciens, to insert into the P. brasiliensis genome the gene responsible for Hygromycin B resistance. In parallel, Soares et al. [50] reported electroporation to deliver the Hygromycin $\mathrm{B}$ resistance gene to the $\mathrm{Pb} 01$ genome. Both studies reported low transformation efficiency and low mitotic stability of the recovered transformants. Among the factors that can be attributed are the multi-budding and multinuclearity of Paracoccidioides yeast cells observed among the isolates used as background strains. 
It was only in 2009 that the first functional study of genes was published, to the enthusiasm of the Paracoccidioides scientific community. Almeida et al. [51] used antisense technology to knock-out the expression of CDC42 in P. brasiliensis yeast cells, an important protein for the control of yeast cell growth and virulence. The authors reported a $49 \%-88 \%$ efficiency in silencing the CDC42 gene. Despite this breakthrough, there is still no efficient gene deletion system based on classical genetic techniques and homologous recombination. The scientific community looks forward to seeing the CRISPR/CAS9 system, which is widely used for functional study of genes in fungal kingdom members, being applied to Paracoccidioides shortly. Even with this delay in the development of appropriate molecular tools compared to other human pathogenic fungi, several studies have been published in the past few years, using the gene expression modulation approach described by Almeida et al. [51-60].

From the first description of the disease in 1908 by Lutz to the present day, a period of more than one century, much progress has been made in understanding the life cycle of this human pathogen. The development of molecular techniques boosted the number of publications related to Paracoccidioides and PCM. Today, more than 2300 published studies can be explored on the Pubmed database (https://pubmed.ncbi.nlm.nih.gov/), which clearly demonstrates the enormous efforts and impressive advance of researchers in understanding this pathogen and its disease. Figure 1 highlights the pioneering studies that paved the way on this long journey. There is still much to clarify and to explore. In this article, we will discuss how all these data accumulated to date can contribute even more to the development of new antifungal strategies to expand the therapeutic range for fighting the disease. 


\section{Paracoccidioides sp}

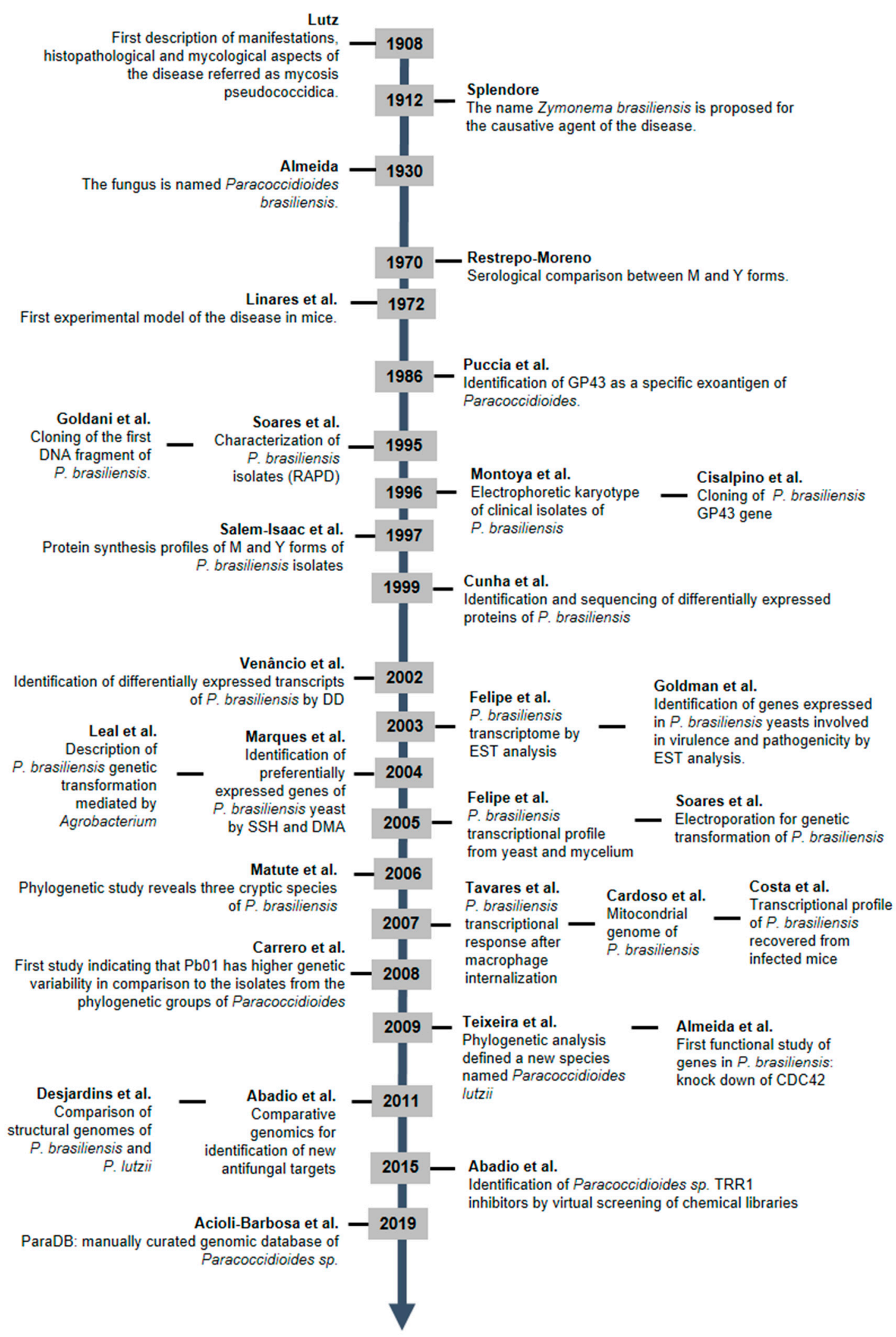

Figure 1. Primary studies related to Paracoccidioides sp. from the first description of the disease to the present day. The timeline herein illustrated for Paracoccidioides findings was based on a Pubmed database using the term "Paracoccidioides" as a query. 


\section{Search for New Therapeutic Options-A Journey}

\subsection{A Starting Point-Available Therapeutic Options}

The achievements of the primary research on Paracoccidioides are undeniable, a history built by various hands. However, issues related to the treatment of patients with PCM still have a distance to travel. PCM treatment is restricted to three groups: polyenes, sulfa derivatives and azoles [61]. Generally, treatment consists of two phases: induction and maintenance. The induction treatment corresponds to the immediate control of the signs and symptoms and the fungal burden reduction to recover cellular immunity, a fundamental step for therapeutic success. The drugs used in this phase are usually more active and of intravenous administration but have more adverse side-effects. Therapy maintenance is usually performed with oral administration drugs and more extended treatment regimes. The reduction of antibody titers is generally a criterion used to start this phase. The treatment usually continues until cure criteria are reached, seeking to reduce the risk of disease recurrence. These criteria are based on four parameters: clinical (absence or regression of disease signs and symptoms), mycological (negative direct mycological examination), radiological (stabilization of pulmonary radiological image patterns), and immunological (antibody titer-negative or stabilized at low levels) [5].

Amphotericin $B(A m B)$, a drug of the polyene class, has a fungicidal effect. The mechanism of action of Amphotericin B, the most commonly studied and well-known, is the interaction with ergosterol, the main sterol in the plasma membrane of fungi. In this case, there is the formation of pores and, consequently, the leakage of small ions and water molecules [62]. Despite studies using computerized modeling of the formed channel [63], other AmB action models have been proposed [64,65]. Anderson et al. have suggested that amphotericin $B$ activity is due to the ergosterol depletion from the lipidic bilayer of the yeast membrane by large extra-membranous aggregates of AmB [64]. Besides, Mesa-Arango et al. [65], demonstrated that reactive oxygen species are essential mediators in the fungicidal effect of AMB. Since 1958, AmB has been a recommended drug for severe PCM cases. In recent years, it has been considered the antifungal of choice for the treatment of PCM, especially in the attack phase. However, it should be noted that this drug has several limitations, such as administration only by intravenous route and nephrotoxicity [66,67]. Although there are currently liposomal forms of Amphotericin $\mathrm{B}(\mathrm{LAmB})$, these present high costs, and maintain several adverse effects, such as fever, chills, tachycardia, tachypnea, and hypertension or hypotension [68]. However, there is no doubt that LAmB has a significantly improved toxicity profile compared with conventional AmB. This fact has encouraged several clinical studies with LAmB, in different situations in which treatment with $\mathrm{AmB}$ is clinically indicated, but the conventional formulation cannot be administered [69].

Several sulfa derivatives have been used since 1940. Sulfamethoxazole-trimethoprim (SMX-TMT) or cotrimoxazole is frequently used, especially in the maintenance phase [70]. This drug is distributed by the Brazilian public healthcare system and its use offers advantages such as low cost, acceptable toxicity profile, the achievement of adequate concentrations in several organs and availability by both oral and intravenous routes [5]. However, therapeutic failure has been described in $5 \%$ of patients, and the main disadvantage is the need for longterm treatments (more than 12 months), followed by adverse effects such as hypersensitivity reactions, leukopenia, megaloblastic anemia and thrombocytopenia [70,71].

In the same fashion, a randomized study performed in three Brazilian hospitals showed a similar therapeutic effect between itraconazole, ketoconazole and sulfadiazine [72]. The antifungal activity of triazoles is predominantly by CYP51 inhibition, a cytochrome P450 enzyme (sterol 14-alpha-demethylase), which prevents the conversion of lanosterol to ergosterol $[73,74]$. The therapeutic success of itraconazole in several patients with active PCM was reported, with a significant reduction in inflammatory infiltrates. The role of itraconazole in the pulmonary fibrosis control caused by PCM is still unclear, since few reports in the literature are available. Among them is one in which fibrosis became more evident after therapy, reaching $81 \%$ of patients treated [75]. In addition, the use 
of itraconazole involves several drug interactions: Warfarin, Calcium channel blockers, Carbamazepine, Cyclosporine, Simvastatin, Midazolam, Rifampicin, Sirolimus, Tracolimus and several antiretroviral drugs [5]. It is important to highlight that co-infection reports of PCM and tuberculosis are described in the literature, as well as of HIV patients with PCM. Thus, drug interaction is a limiting factor that should be taken seriously. Despite the advent of newer-generation triazoles, such as voriconazole and posaconazole, itraconazole is considered the main azole derivative used in clinical practice, with satisfactory results in non-hospitalized PCM patients [76,77]. This generation of antifungals can be considered as potential substitutes for itraconazole; however, they are still high cost and new clinical evidence needs to be published $[5,66]$. Another point to consider is that several azoles have renal excretion. In this sense, the dose should be adjusted in patients with renal disease [5].

The cell wall is in fact a drug target with great therapeutic potential. Glucan synthase (fks1) is listed among the potential targets for the further development of antifungals [78]. A recent review has reaffirmed the potential of this target [79]. However, the cell wall of Paracoccidioides is altered when this pathogen changes from mycelium to yeast form. $\beta-1,3-$ glucan is replaced by almost entirely $\alpha-1,3$-Glucan when this species enters the pathogenic yeast phase [80]. Thus, echinocandins showed no promising antifungal activity in the in vitro assays against Paracoccidioides sp., especially against yeast $[81,82]$. In addition, the most recent inhibitors Ibrexafungerp [83] and rezafungin [84] have not yet been evaluated for in vitro or in vivo activity in the PCM model.

In the specific case of PCM, even though treatment achieves success using the available therapeutic options, limitations related to nephrotoxicity, prolonged treatment and inability to control pulmonary sequelae are a reality among patients. Fortunately, the technological progress of the last few decades has made a large number of genomes from human fungal pathogens available. Therefore, the advances that the "-omics" era provided are undeniable, and a start has been made in which basic knowledge is widely used in applied research, such as new antifungal development [78,85-89].

\subsection{Comparative Genomics Searching for Drug Targets}

The development of antifungal agents with a broad action spectrum and minimal human toxicity is an urgent demand [87]. Currently, several approaches are available in the search and development of drugs [90-93]. Planning based on structure and mechanism of action has proven to be an efficient and less expensive strategy for developing new drugs [94]. A critical study showed that the most common drug targets are enzymes, particularly oxidoreductases, transferases and lyases. These protein targets are involved in binding, signaling and cellular communication. Usually, they are found in the cell membrane and in the cytoplasm, and are rarely present in organelles [95].

Comparative genomics is an important tool for the initial step in searching for new compounds for treating severe mycotic diseases, including PCM. One strategy for searching for new antifungal targets is identifying essential genes that are important for the cell viability of the pathogen. The access to the complete genomic sequences of pathogenic fungi, including P. brasiliensis and P. lutzii, allowed target genes to be identified using bioinformatics techniques [78]. A comparative genomic analysis was performed using 57 orthologous genes present in P. brasiliensis, P. lutzii, C. albicans, Aspergillus fumigatus, Blastomyces dermatitidis, Coccidioides immitis, Cryptococcus neoformans and Histoplasma capsulatum. Among these selected genes, 55 are essential for C. albicans and/or A. fumigatus [96,97] and two are required for fungal survival within the host $[98,99]$. The alignments of these gene sequences and manual curation following the criteria, such as essential or needed for fungal survival, found in all the pathogenic fungi, and absent in humans, provided a list of 10 potential antifungal drug targets [78]. This work proposed a starting point in the search for new therapeutic options to treat fungal infection, cited more than 63 times, according to the metrics of Web of Science. Since that time, essential genes, pathogen-specific metabolic pathway enzymes and virulence and pathogenicity factors have been widely explored $[87,100,101]$. Thus, identifying essential genes preserved in several pathogens, 
which has also been used as a strategy, pointed to a very accurate way forward when selecting proteins from the thioredoxin system as potential drug targets (Figure 2A).

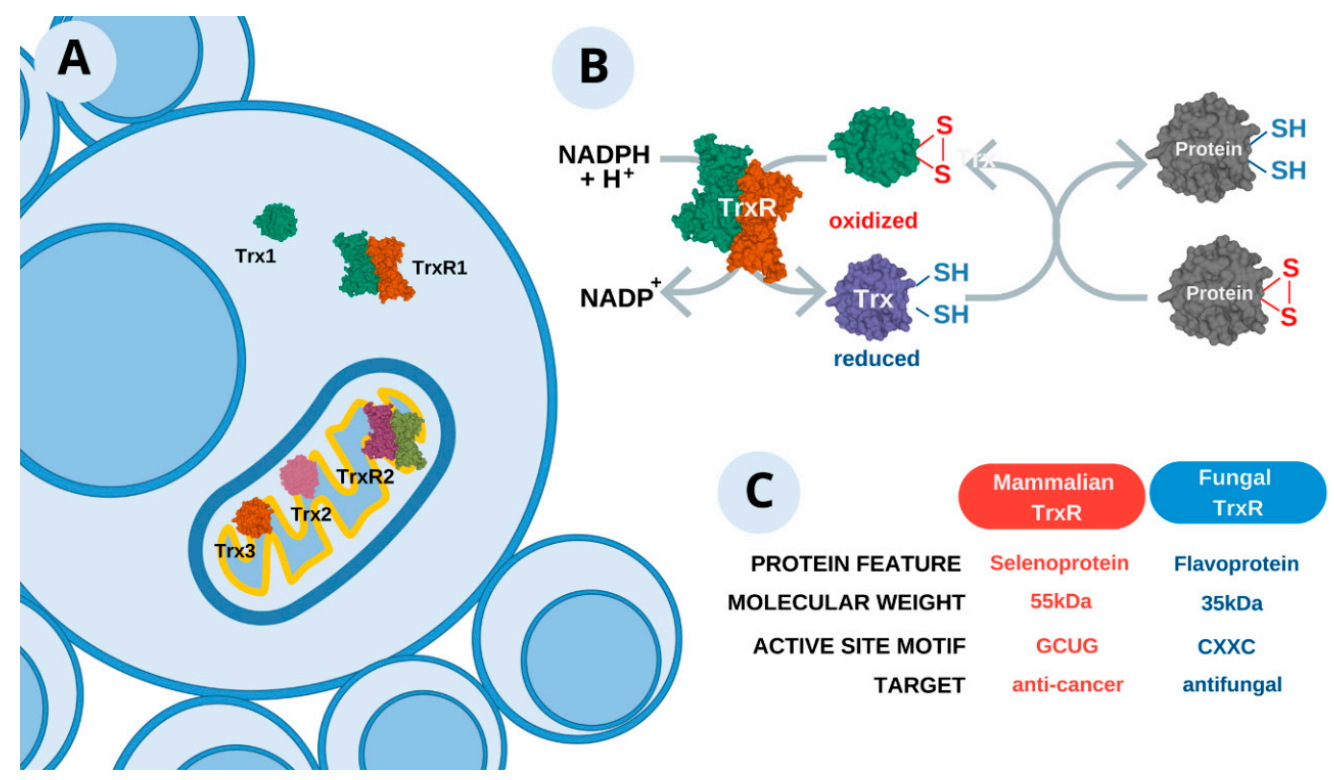

Figure 2. Thioredoxin system, an important means to control oxidative stress. (A) Cyto-localization of the thioredoxin system in Paracoccidioides sp. Three isoforms of thioredoxin were identified, namely Trx1 (cytoplasmatic) and Trx2 and Trx3 (mitochondrial). Thioredoxin reductase (TrxR) also participates in this system, which presents two forms, one in each compartment. (B) Schematic representation of the mechanism of action. The oxi-reduction reaction occurs so that cellular proteins are constantly available to control situations of the reactive species inside the fungus. (C) Comparison from thioredoxin systems between human and fungi.

\subsection{Thioredoxin System-A Promising Approach \\ 2.3.1. General Definition}

Prokaryotic and eukaryotic cells have different redox systems, and among them is the thioredoxin system [102]. In this complex system, two elements are essential: the protein thioredoxin (Trx) and the enzyme thioredoxin reductase (TrxR, EC 1.6.4.5, named in many articles as Trr1). Trx are thermostable and low molecular mass proteins. The structure of this protein has a fold consisting of a central B-sheet, with five flanked by four $\alpha$-helices. The Trx is an antioxidant known as a redox-sensitive molecule with a highly conserved active site (-Cys-Gly-Pro-Cys-), and catalyzes oxidation-reduction reactions by electron transfer dynamics (Figure 2B) [103]. This protein is reduced by TrxR, a selenocysteine containing protein and belonging to the flavoprotein class which binds flavin adenine dinucleotide (FAD) and nicotinamide adenine dinucleotide phosphate (NADPH) [103-107]. The pattern of binding and electron transference between NADPH and its FAD cofactor, besides the presence of TrxR (which catalyzes the reduction of Trx), are important for the maintenance of the reduced form of Trx [106], since most of the actions of Trx are performed when it is in the reduced state, stable and functional [108]. The active site of TrxR is found in the binding domain to NADPH, and the transfer of electrons from NADPH to the FAD-binding domain is essential for protein stability [109]. When the FAD domain receives electrons, it promotes protein rotation to allow the electrons to transfer to the active site and, in this way, the transitory binding of the NADPH-mediated TrxR to the oxidized Trx occurs [110]. The reduced Trx acts as a protein disulfide reductase and, when the active dithiol site interacts with oxidized cysteines of proteins, there is a thiol-disulfide exchange process forming an oxidized Trx [106].

The molecular weight of TrxRs classifies them into two important groups (Figure 2C). Those of high molecular weight (55 kDa for each subunit) are present in higher eukaryotes, 
and contain a selenocysteine in their active site [107]; furthermore, they can reduce various substrates in addition to thioredoxin [106]. This protein is part of the class I family of the pyridine nucleotide-disulfide oxidoreductase and has an active redox site composed of a seleno-protein forming the Gly-Cys-Sec-Gly domain. This is required to form a selenony-sulfide in the oxidized enzyme which is reduced by the active site of the other subunit in the dimeric enzyme [111]. In comparison, those of low molecular weight (35 kDa for each subunit) are present in prokaryotes, archaea and lower eukaryotes, such as fungi [106]. This enzyme is a member of the class II family of the pyridine nucleotidedisulfide oxidoreductase [112]. In the redox system, they are restricted to the reduction of thioredoxin [107] and, in addition, do not have selenium in the active site, leaving only cysteine [113]. Despite the similar function of isoforms, the molecular structure is different and these characteristics are essential for target selectivity [114].

The functions of the thioredoxin system are directly involved with cellular homeostasis. Various pieces of scientific evidence demonstrate the importance of this system in redox cell balance, repair of mutagenic DNA, cell growth and survival [106,115,116]. In mammals, three isoforms of Trx and TrxR have already been identified, differentiated by cyto-location. Trx 1 and TrxR1 are present in the cytoplasm and are dominant forms $[117,118]$. In the mitochondrial location, Trx2 and TrxR2 are present $[117,118]$. Another Trx isoform localized in the mitochondria is Trx3. This 14-kDa protein was described in Saccharomyces cerevisiae containing the characteristic thioredoxin active site (WCGPC) [119]. Trx3 possesses two additional cysteine residues Cys57 and Cys6, overlaying the activity of the glutathione reductase system [120]. The sequences of all Trx and TrxR isoforms were predicted for Paracoccidioides sp. (Figure 2A).

In humans, increased Trx expression has already been seen in different types of cancer such as colorectal [121], lung [122], pancreatic [123], and gastric [124]. Increased oxidative stress increased in cancer cells may contribute to reduced apoptosis, up-regulation of cell growth, increased invasion, or even regulation of angiogenesis. Therefore, a strategy used in anti-cancer therapy is to obtain inhibitors that work selectively on the cytosolic isoform of thioredoxin reductase, reducing damage in normal cells [125].

\subsubsection{Fungus Selectivity}

Research using the thioredoxin system as a target for treatment for fungal infections has increased in recent years [97,114,126-131]. The identification of essential genes is a strategy that elucidates new targets for antifungal therapy, and when widely conserved in fungi, there is an increased interest in acting as new targets for drug design [97]. Blocking the thioredoxin system is an excellent strategy that makes the fungus vulnerable to reactive oxygen species [129] and, therefore, its performance is essential for the vitality of fungi such as C. neoformans [126], C. albicans [114] and A. fumigatus [97].

Studies with $C$. neoformans have confirmed that this protein is induced during oxidative stress and showed that Trr1 is an essential gene for this species. C. neoformans $\operatorname{TrxR}$ is present in mitochondria and cytoplasm, participating imperatively in virulence [126,132]. The knowledge of the three-dimensional crystallized structure of this protein has been established, and it is a key point for future studies aimed at understanding the structural properties, catalytic activity and molecular mechanisms of Trx in C. neoformans [133]. As for C. neoformans, studies also show the importance of essential genes for the fungal genus Aspergillus. Hu et al. [97] identified the trr1 gene as essential for A. fumigatus vitality, and in addition this characteristic directly reflects the virulence of the pathogen [131]. For $A$. fumigatus, the thioredoxin system also acts in the maintenance of cellular redox homeostasis and, therefore, TrxR also presents a potential target for new antifungals [134]. Although other authors have already mentioned TrxR as a good target for antifungal therapy against C. albicans, it was only in 2016 that Godoy et al. [127] demonstrated the structural and functional characterization of the recombinant thioredoxin reductase from C. albicans. This recombinant protein effectively induced anti-CaTrxR antibodies that reduced the fungal burden in a disseminated candidiasis experimental model. 
Historically, the Trx system is an important drug target for Paracoccidioides spp. [78, $114,128,129,135]$. The thioredoxin system investigation started in 2003 [35] in which genes that were supposedly involved in oxidative stress response expressed in P. brasiliensis were identified, including the trx gene. Additionally, Abadio et al. [78] used the comparative genomic tool and outlined the identification of potential antifungal therapy targets. Four drug targets were selected, including the enzyme Trr1. Recently, Oliveira et al. [129] showed the presence of Trr1 in the P. lutzii cell wall, highlighting it as an important target for therapeutic antibodies. The accumulated evidence that the TrxR enzyme of the thioredoxin system is required for the intracellular redox balance and, consequently, influences fungal viability, prompted researchers to search intensely for specific inhibitors against TrxR as a strategy for the development of new antifungals.

\subsection{In Silico Strategy for New Antifungal Development}

Computational methods have come to play a significant role in drug design. Simulations based on the target structure bring a greater chance of success for drug development in less time [136] (Figure 3). The target prediction for drug discovery can be based on structural models available in databases, resulting from X-ray crystallography or NMR spectroscopy [137]. The best binding sites are identified by computational tools, according to physical-chemical properties, and thus the docking for selection of inhibitors can start by virtual screening [138]. The number of three-dimensional structures that have been resolved experimentally is growing exponentially, totaling 171,588 structures deposited by November 2020. This situation is not the same for fungi, much less for the genus Paracoccidioides. The Protein Database statistical data (https:/ /www.rcsb.org/stats) indicate that fungal proteins represent about $6 \%$ (10,295 structures). Until now, only one structure from Paracoccidioides has been solved by X-ray crystallography, a nucleotidyl-transferase-like antigen, named $\mathrm{Pb} 27$ [139].

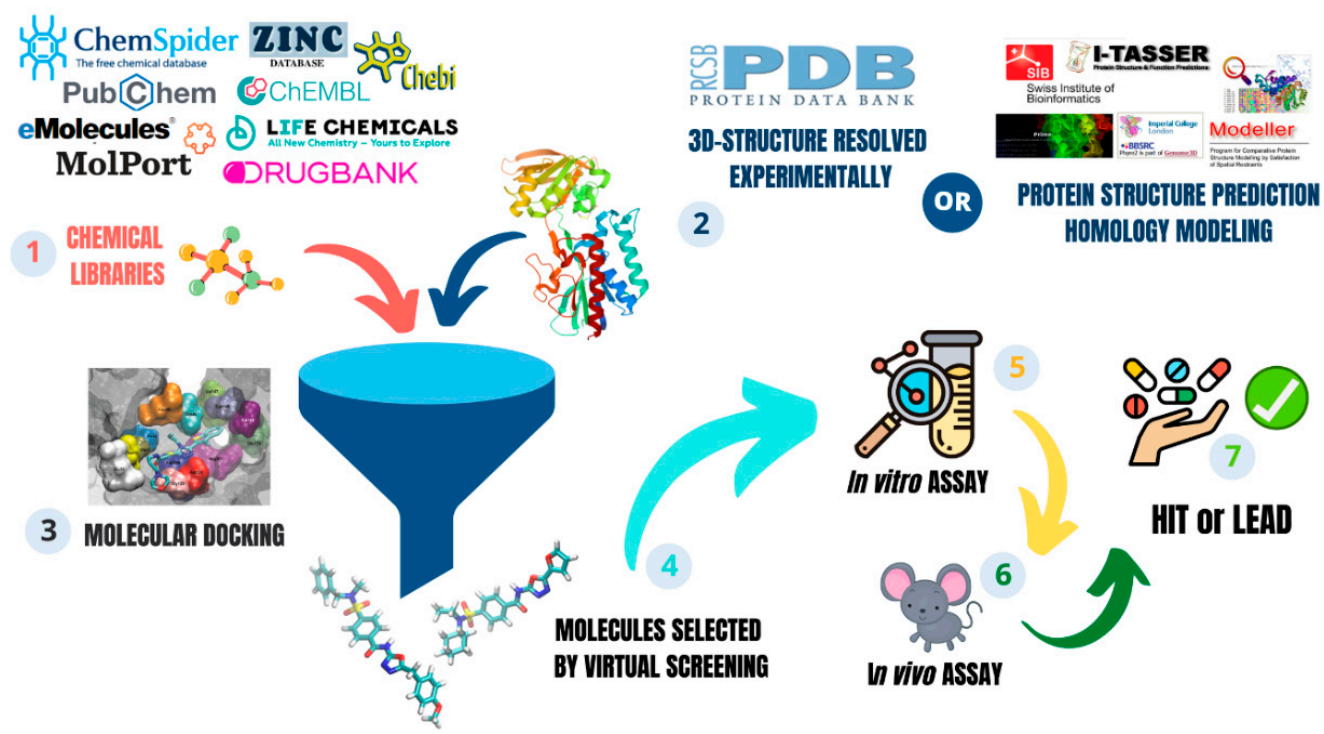

Figure 3. Drug design by in silico approaches. This process can be divided into at least seven steps. (1) Prepare the molecules libraries with filters such as Lipinski's rule. Currently different databases are commercially available: https://www.molport. com/shop/index; http:/ /www.chemspider.com/; https://zinc.docking.org/; https://www.ebi.ac.uk/chebi/; https://reaxys. emolecules.com/index.php; https://go.drugbank.com/; https://www.ebi.ac.uk/chembl/; https://pubchem.ncbi.nlm.nih. gov/; https://lifechemicals.com; (2) Prepare the target protein, either from the experimentally solved protein database (https:/ / www.rcsb.org/) or by homology modeling (https:/ / salilab.org/modeller/; https://zhanglab.ccmb.med.umich.edu/ITASSER/; http:/ /www.expasy.org/resources/swiss-model; https://robetta.bakerlab.org/; https://www.schrodinger.com/ prime; (3) Analyze the in silico data in search of new molecules (4) Perform the experiments in vitro; (5) Analyze the results in vitro to start point (6) in vivo experiments; (7) Compounds that meet all the requirements can sequence with the hit-tolead process. 
Thus, by homology modeling, protein structure prediction is a reality for the groups working with Paracoccidioides spp. Indeed, Abadio et al. [77] obtained three-dimensional structures of two proteins by homology modeling from P. lutzii: thioredoxin reductase and alfa-1,2-mannosyltransferase. The three-dimensional models allowed the identification of relevant information about these proteins, such as the conserved domains and the residues of the active site [77]. The 3D-structure of other Paracoccidioides proteins was built by in silico tools for virtual screening application, such as homoserine dehydrogenase (EC 1.1.1.3) [140], chorismate synthase (EC 4.2.3.5) [141] and isocitrate lyase [142].

\subsubsection{Virtual Screening}

Virtual screening allows a search for several chemical libraries of small molecules and selects those that best interact with the specific target's catalytic site [94,143-145]. The application of this technique is well accepted, mainly in the lead discovery phase [146,147]. Unlike the empirical choice of compounds, the selection of these specific target compounds reduces the amount of in vitro and in vivo assays performed to prove their activity, reducing costs, as well as the time spent comparing with chosen compounds without a rational selection [148,149]. The search for potential inhibitors of target enzymes can be performed in different chemical libraries, with thousands of molecules. After selection, hit compounds could then be synthesized and acquired for in vitro and in vivo validation (Figure 3). In recent years, the identification of thioredoxin system inhibitors by virtual screening has been a success story.

In collaboration with Maigret's group (Loria, France), the best twelve small molecules that interact with the Trr1 from P. lutzii were virtually selected. These molecules were purchased and three presented specific antifungal activity against $P$. lutzii and P. brasiliensis. By using enzymatic assays, the recombinant thioredoxin reductase from $P$. lutzii was also inhibited by these molecules [114]. Afterward, molecules with an extended action spectrum for other fungal species of worldwide relevance-Candida and Cryptococcus - were selected as potential ligands of the active conformation of Trr1 by virtual screening. Crystallography studies revealed that the NADPH and FAD domains are located on opposite sides of the molecule, requiring a significant conformational change for electron transport to occur $[150,151]$. In this approach, two small molecules (from the oxadiazoles class) were selected as Trr1 inhibitors of three pathogenic fungi: Candida spp., Paracoccidioides spp. and Cryptococcus spp. [152]. These new compounds proved to be broad-spectrum with antifungal activity against $C$. albicans. The inhibitory activity in vitro was $64.9 \mu \mathrm{M}$, without cellular toxicity and, most importantly, significantly reduced the fungal burden on the kidneys of mice in the candidemia experimental model [128]. One of these oxadiazole compounds, named LMM11, showed activity against C. krusei with MICs ranging from 65 to $129.9 \mu \mathrm{M}$, and it also succeeded in reducing colony-forming unit (CFU) recovered from the kidneys of infected mice with this clinically-relevant pathogen, mostly involved in hospital infections [130]. The two oxadiazoles (LMM5 and LMM11) selected against TRR1 showed a range of inhibitory action from 2.03 to $71.99 \mu \mathrm{M}$ against nine isolates of Paracoccidioides spp. They also showed a significant reduction in CFU recovered from infected and treated mice and found no toxicity in a murine PCM model [135].

Another molecule selected by virtual screening against Paracoccidioides protein was CP1, a derivative of quinolinic alkaloids. This molecule targeting chorismate synthase from $P$. brasiliensis showed excellent antifungal activity against many clinical isolates from Paracoccidioides spp. [139]. In this same sense, Bagatin et al. [140] selected inhibitors of homoserine dehydrogenase (HSD) from a library of natural products, which showed specific antifungal activity against Paracoccidioides spp. The two new amino acid derivative compounds, HS1 and HS2, exhibited MICs of 260.9 and $123.4 \mu \mathrm{M}$, respectively, against P. brasiliensis (Pb18 isolates) and $246.81 \mu \mathrm{M}$ against $P$. lutzii. In addition, synergic activity with itraconazole was observed [140]. Given the promising results using HSD as a target, a new virtual screening was performed to search for optimized compounds. The molecule HS9 (Zinc2123137) presented fungicidal activity that was more promising than HS2, with 
MIC values of $23.44 \mu \mathrm{M}$ and low cytotoxicity in human cell lines [153]. Two recent studies indicate the synthesis of lead molecules from these hit molecules selected by virtual screening [154,155].

From the theoretical model of malate synthase, four compounds were selected by virtual screening against this enzyme present in fungi and absent in mammals. The compounds selected presented moderate antifungal activity, with MIC values varying from 8.76-249.57 $\mu \mathrm{g} / \mathrm{mL}$. Unfortunately, these compounds present specific toxicity in cell lineage [146]. A promising hit molecule was selected by virtual screening against alpha-1,2mannosyl transferase from P. lutzii [156]. This molecule, named MOL3, presented in vivo antifungal activity against Paracoccidioides spp. (data not shown), and for many Candida species, especially Candida parapsilosis [157]. Virtual screening to search for compounds chemically related to a molecule with known antifungal activity may be an interesting approach. Three chalcone derivatives, selected by this approach, showed promising results in vitro, with MIC values varying from 2.9-12.6 $\mu \mathrm{M}$ against different Paracoccidioides spp. isolates and low cytotoxicity [158]. Recently, isocitrate lyase from P. brasiliensis was modeled by homology modeling, and the virtual screening was performed with many natural compounds from the ZINC database. The best-selected compound (ZINC4559339) presented values MIC of $19.1 \mu \mathrm{M}$ in P. brasiliensis with a fungicidal effect at this concentration [142]. Therefore, ten different molecules showed promising values of antifungal activity and absent of toxicity in vitro (Figure 4 ).

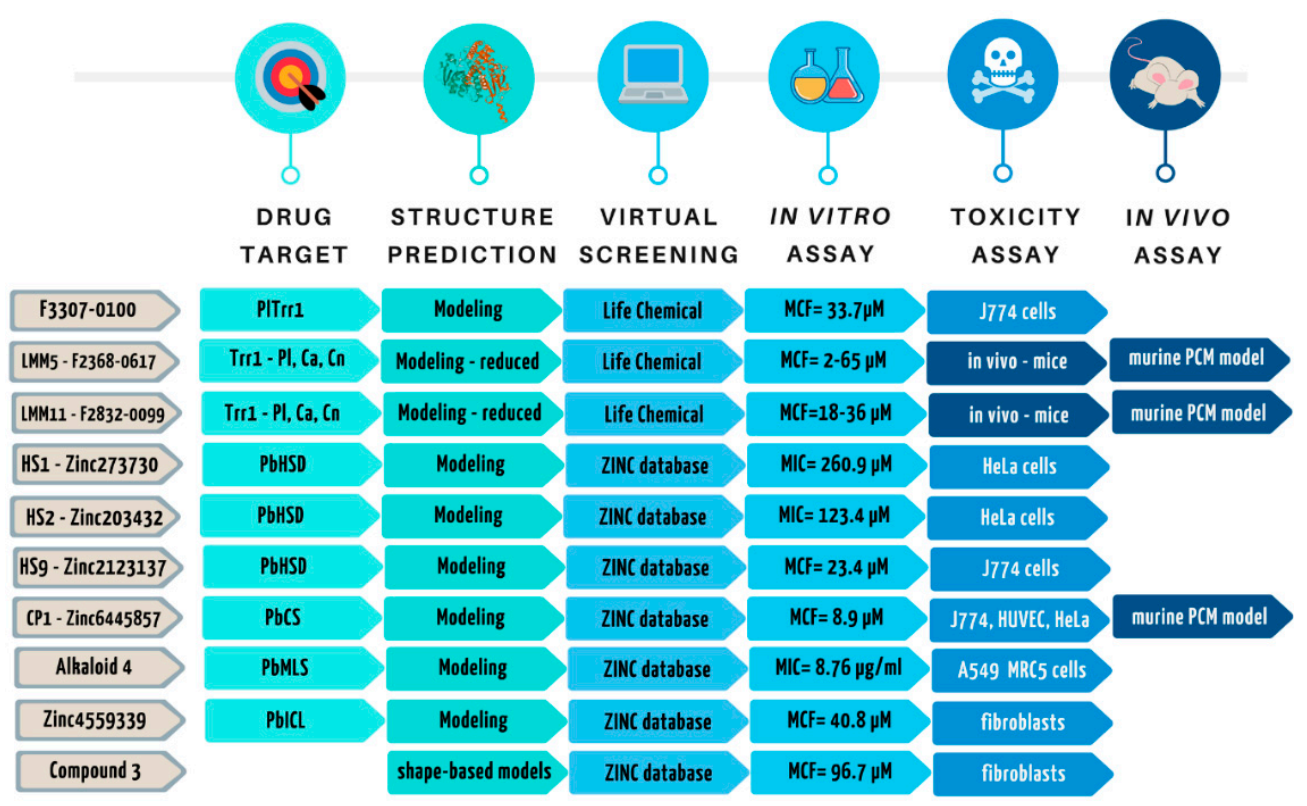

Figure 4. Comparison of selected molecules by virtual screening. Ten different molecules showed promising values of antifungal activity and absent of toxicity in vitro. Only three molecules were tested in an experimental model of paracoccidioidomycosis (PCM). F3307-0100 [114], LMM5 and LMM11 [135], HS1 and HS2 [153], HS9 [140], CP1 [141], alkaloid 4 [146] Zinc4559339 [142], Compound 3 [158].

\subsubsection{Drug Repositioning}

Drug repurposing or repositioning aims at a new indication for drugs already approved to treat other diseases and/or whose mechanism of action or targets are already known [159]. This methodology directly reduces time and costs for the drug to reach the clinical trial stage [160], since, for example, data on pharmacokinetics and pharmacodynamics may already be available [161]. Satisfactory results have already been shown in therapy for parasitic diseases [162] and cancer [163]. Drug repositioning appears as a viable alternative for discovering new drugs against mycoses [164] and other neglected diseases [165]. 
Concerning new antifungals in the literature, we found a significant number of studies on targeted drug repositioning in mycoses caused by Candida spp. [166] or Cryptococcus spp. [167]. However, with dimorphic fungi, such as Paracoccidioides spp., there are still few studies described. In this context, the antiviral raltegravir showed activity against Paracoccidioides isolates [168]. Ligand-based and structure-based (molecular docking) computational methods were used for repositioning. The selected compounds were chemically similar to two-hit compounds previously selected against thioredoxin reductase, with promising antifungal activity. All the six compounds evaluated showed antifungal activity against the genus Paracoccidioides, particularly raltegravir (MIC: $36 \mu \mathrm{M}$ for P. brasiliensis and MIC: $72 \mu \mathrm{M}$ for $P$. lutzii). Additionally, this antiviral drug showed promising antifungal activity against experimental murine paracoccidioidomycosis, with a significant reduction of the fungal burden and decreased alterations in the lung structure of treated mice [168].

Oliveira et al. [169] developed computational drug repurposing - chemo-genomicsto identify anti-PCM activity drugs. The goal of chemo-genomics is to establish the molecular relationships of ligands and targets using genome data [170], within the concept that "similar targets have similar ligands" [171]. Studies with chemo-genomics in silico have already appeared satisfactory for drug repositioning in species of parasitic Schistosoma mansoni [172]. The old-drugs that have been repositioned belong to antineoplastic (vistusertib and BGT-226) and azole compounds (bifonazole, luliconazole, butoconazole and sertaconazole). These compounds presented significant antifungal activity [169].

\subsection{Drug Targets Discovered from Natural Products}

Natural compounds and derivatives are still widely used in the search for molecules with antimicrobial potential [101]. The variety of bioactive secondary metabolites present in plants has been an inexhaustible source of compounds with antifungal activity [173], including against PCM. Since 1993, the antifungal activity of ajoene (natural garlic compound) against $P$. brasiliensis has been known [174]. In 1997, the same authors suggested that the anti-P. brasiliensis activity may be due to the blocking of phosphatidylcholine biosynthesis [175]. Maluf et al. [176] confirmed the activity in vivo of ajoene in experimental PCM and Thomaz et al. [177] indicated the additive effect between ajoene and sulfamethoxazole/trimethoprim.

Recently, OMICs tools have helped describe the action mechanisms of these natural products and their possible molecular targets. Oenothein B (OenB), a macrocyclic hydrolyzable tannin dimer extract of Eugenia uniflora L. (a Brazilian Cerrado plant), inhibited the $1,3-\beta$-D-glucan synthase (PbFKS1) transcript accumulation in the P. brasiliensis isolate Pb01. This natural compound interferes with the fungal cell morphology [178]. Other enzymes that also participate in cell wall synthesis have been modulated by OenB, such as those expressed by GLN1 and KRE6 genes [179]. Enzymes that participate in cell wall synthesis and those involved in the protein mannosylation process have been described as targets of drugs by Abadio et al. [78].

A series of $\beta$-carboline alkaloids isolated from Rubiaceae and Apocynaceae species showed activity against Paracoccidioides spp. and in silico experiments suggest interaction with malate synthase (MLS) [180]. PbMLS acts on the glyoxylate cycle and in the allantoin degradation pathway [181] and it is considered a multifunctional and versatile protein [182] Argentilactone is the principal constituent of the essential oil from the Brazilian savanna plant Hyptis ovalifolia. This compound and its semi-synthetic derivatives were able to inhibit the activity of isocitrate lyase from P. lutzii (PbICL), yeast cell growth, and differentiation from mycelium to yeast [183]. This is another enzyme of the glyoxylate cycle that could be exploited as a drug target [184].

Antifungal activity of thiosemi-carbazide camphene derivative (TSC-C) in isolates of Paracoccidioides spp. was also demonstrated. The transcriptome analysis suggests this derivative was related to the induction of the ROS formation in Paracoccidioides spp. [185]. By chemo-proteomics, Borba et al. [186] suggest that thiosemi-carbazides (TSCs) and TSC-C were multitarget compounds with an effect on several essential mechanisms for Paracoccid- 
ioides such as electron-transport chain, cell cycle, ROS formation, cellular metabolisms and mycelium-yeast transition. Thus, the crucial enzymes and metabolic processes were described as potential targets of promising antifungal molecules, mainly natural compounds and synthetic derivatives.

\section{Nanotechnology as an Approach for Alternative Therapies}

Different strategies to improve PCM therapy are under development, many using the benefits promoted by nanotechnology (Table 1), whether carrying molecules that act as immunomodulatory boosts such as the peptide P10 [187,188], a DNA vaccine [189] or the scFv fraction from a recombinant antibody [190]. These carriers may also carry conventional drugs, such as amphotericin B [191,192] and itraconazole [191]. Such strategies were able to improve murine treatment for PCM significantly, demonstrating that the formulation of these compounds in nanostructured systems had benefits such as reduced dosage and side effects as well as positive modulation of the immune response of animals in the fight against fungal infection.

Table 1. Different strategies using nanotechnology for the treatment of experimental PCM.

\begin{tabular}{ccc}
\hline Type of Nanostructures & Encapsulated Compound & Reference \\
\hline PLGA + DMSA & Amphotericin B & Amaral et al. [191] \\
PLGA + DMSA & P10 peptide & Amaral et al. [187] \\
Liposome and PLGA & DNA Hsp65 vaccine & Ribeiro et al. [189] \\
Magnetic nanoparticles & Amphotericin B & Saldanha et al. [192] \\
PLGA & scFv & Jannuzzi et al. [190] \\
PLGA + DMSA & Itraconazole & Cunha-Azevedo et al. [193] \\
Chitosan & P10 peptide & Rodrigues et al. [188] \\
\hline
\end{tabular}

PLGA: copolymer of lactic-co-glycolic acids; DMSA: dimercapto-succinic acid.

Nanostructured drug delivery systems have been developed considering the principles of nanotechnology, which deals with materials or tools on a small scale $\left(10^{-9} \mathrm{~m}\right)$. In this dimension, materials exhibit different physical and chemical properties, allowing an efficient association with other materials, including antifungals [194,195]. For the construction of these systems, a diversity of materials is used, chosen from the characteristics required for the final formulation.

Because of the small size of these drug delivery systems, the molecules (drugs and natural compounds) associated with these nano-formulations also perform differently, reaching body regions that would not be possible or would be reached less efficiently if administered in a conventional formulation. These nanostructured systems are appreciated for being used to deliver molecules that can be easily degraded when administered in vivo, such as peptides or unstable molecules [196]. In the case of polymeric nanoparticles, these molecules can be surrounded by a polymeric matrix protecting them from the action of enzymes present in the physiological environment, thus increasing their half-life [197]. In addition, nanoparticles can be functionalized by binding, on their surface, those molecules that exhibit tropism for specific organs or cells, resulting in a sophisticated and efficient drug delivery system.

As far as we know, one of the first studies using nanotechnology for drug delivery in experimental PCM was carried out by our group [191]. In this strategy, it was possible to incorporate the antifungal amphotericin B in a polymeric formulation prepared using the copolymer of lactic-co-glycolic acids (PLGA) and functionalized with dimercaptosuccinic acid (DMSA), which presents tropism to the lungs [198]. Amphotericin B was chosen because it is a drug that, despite its excellent fungicidal activity, in the conventional formulation of sodium deoxycholate causes unwanted and severe side effects, such as nephrotoxicity and hepatotoxicity [199].

In this drug delivery system, it was possible to incorporate three times the daily dose prescribed for the treatment of PCM using amphotericin B [191]. This strategy proved 
to be effective and it was possible to administer the treatment every three days since the degradation of the PLGA was slow, releasing the drug for up to six days. Complementary studies to evaluate the biodistribution of nanoparticles labeled with technetium-99 showed that these nanoparticles were distributed to different organs, not only in the lungs, as expected by the fact they were functionalized with DMSA [200]. These nanoparticles may have slowly degraded in organs and the amphotericin B was released in the circulation, exerting the antifungal activity.

The association of amphotericin B with magnetite nanoparticles pre-coated with a double layer of lauric acid was also investigated [192]. This system proved to be an alternative to the conventional formulation of sodium deoxycholate for this drug, since in vivo treatment results were similar. An interesting point for this type of nanostructure is its ability to reach extremely specific regions of the organism. In some situations, such as granulomatous lesions, magnetic nanoparticles can be submitted to an alternating magnetic field for better drug action at the site of infection [201]. This technology is still under development and improvement, but it can bring benefits when generating heat, since an alternating magnetic field influences these magnetic nanoparticles. However, the toxic potential of this type of nanostructure must be considered, mainly concerning the coating and functionalization of this type of nanoparticle [202], as they are prepared from iron oxide and, considering the long duration of the antifungal treatment with multiple doses, can cause accumulation and be harmful to the patient.

Polymeric nanoparticles functionalized with DMSA were also evaluated to encapsulate itraconazole [193]. The nanoencapsulation of fungistatic compounds, such as itraconazole, is an important therapeutic option because of the nature of these drugs, whose mechanism of action works by inhibiting the growth of new cells, which could be considered a risk for the development of drug resistance [203,204]. The incorporation of itraconazole in these nanoparticles promoted a more significant accumulation in the lungs, liver and spleen, sites of Paracoccidioides spp. infection, which increases the efficiency of this class of antifungals.

Some materials used in the preparation of nanoparticles slightly stimulate the immune system. Once in contact with biological fluids, the nanoparticles may be captured by macrophages $[205,206]$. In some cases, this is desirable, when working with vaccines or immunomodulatory molecules. Some studies have explored the potential of nanoparticles as an adjuvant in the treatment of PCM.

In one of these studies [190], the adjuvant capacity of PLGA was investigated for singlechain variable fragments $(\mathrm{scFv})$ of a recombinant antibody for gp43, the main antigen for PCM [207]. When incorporated within PLGA, scFv presented an increase in its protective capacity in animals challenged with $P$. brasiliensis. The results were also observed when the P10 peptide, also a fragment of gp43, was incorporated into PLGA [187], in which a 20-fold reduction in the amount of P10 needed to trigger the immune response was achieved. It is important to highlight that when complexed within the polymer, other adjuvants such as Freud's were not needed, although these are necessary when using the free molecules. This is auspicious, since there is no need to use adjuvants in a possible therapy using this strategy.

Whereas both $\mathrm{scFv}$ and the P10 are very unstable molecules for application in a physiological environment, as they can be easily degraded by peptidases, once incorporated in these polymeric nanoparticles they are protected, while remaining in circulation for a prolonged time [196]. On the other hand, nanoparticles may be phagocytized and thus deliver the antigen directly to phagocytes, allowing efficiency in triggering the protective immune response [205]. This type of nano-formulation can be administered by different routes, such as intramuscular or intranasal. In a study comparing the immunomodulatory potential of a DNA vaccine, DNAHsp65, for the treatment of PCM [189], liposomes and PLGA nanoparticles were evaluated for delivery of DNA Hsp65. Both formulations were shown to be effective in treating infection, although they received a dose four times lower. 
The systems proved to be efficient, but the group treated with liposomes received it intranasally, making this vehicle more attractive for antifungal therapy in humans.

The intranasal administration route was also chosen to evaluate a nanostructured formulation for the P10 peptide considering the mucosa present in the nasal route. Thus, polymeric nanoparticles were prepared with chitosan [188], Chitosan is a natural cationic polymer, biocompatible, biodegradable and mucoadhesive, which can interact electrostatically with the anionic mucin present in the airway [197]. The results indicated a 20-fold reduction in the amount of peptide needed to present an efficient protective immune response in animals. Considering the potential of nanotechnology presented by studies using nano-formulations for the treatment of PCM, it could be explored to develop an even safer and more efficient therapy for the treatment of diverse fungal infection.

\section{Challenges and Prospects}

Despite the relevance of fungal infections, especially with the increase in life expectancy of individuals affected by chronic degenerative diseases and, consequently, more people in conditions of immunosuppression, interest from the pharmaceutical industry is still limited. This fact is due to several issues, such as the absence of notification of fungal infections, the type of population affected and the endemic character of some mycoses, as is the case of PCM. Additionally, PCM was recognized as a neglected disease by the scientific community only a short time ago, not being included on the list of neglected diseases of the World Health Organization. Therefore, the development of new therapeutic options for fungal infections is a challenge for academia.

Historically, development of a new drug from laboratory research to its arrival on the market takes around 10 to 15 years and requires a high investment (Food and Drug Administration). The cost of a new drug is the sum of the values of the pre-clinical and clinical phase, and the cost of developing new drugs has increased over the years. Therefore, to place an antifungal drug in the big pharmaceuticals' pipeline does not seem to be something that attracts interest. In this context, rational drug design has been pointed out as a cost-effective alternative to traditional approaches. The in silico methods have reduced the costs and time associated with the initial stages of drug development. These advances, which catalyze the drug design process, were only possible with the rapid development of computer hardware, software and algorithms. These tools allowed researchers to think about the possibility of making viable new therapeutic options for fungal diseases, among them paracoccidioidomycosis, the object of study of many researchers in Brazilian medical mycology.

This process was only possible with advances in basic research into this fungus. The contribution of researchers working with Paracoccidioides to progress in medical mycology is undeniable, as much data was generated in the areas of genomics, proteomics, in silico methodologies, nanotechnology, diagnostic tools and even vaccine development. Comparative genomics, as well as proteomics, enables studies and description of new drug targets that have been rapidly explored in the search for new therapeutic options. These approaches have contributed to a crucial point, which is the activity profile of molecules. Several authors have discussed the importance of antifungal activity as a fungicide. However, combining fungicidal activity and low side effects or toxicity is still a challenge when working with fungi, eukaryotic microorganisms that share very similar biological systems as hosts.

In fact, several publications and patents have described promising compounds and molecules for PCM treatment, some of which have already passed important stages, such as the initial pre-clinical trials. However, some bottlenecks must be overcome in order for these promising molecules to work more effectively and reach the next level, the much-dreamed-of clinical trials. First is the need for large quantities of these molecules, purchased or synthesized, to move forward in the next stages. Second is the need to develop pharmaceutical formulations that provide an adequate administration route and sufficient bioavailability. In addition, pharmacokinetic and pharmacodynamic studies, 
either through computer simulations or laboratory analysis, are essential. Finally, the costs need to be lower, so that all these obstacles can be effectively overcome.

To this end, researchers working specifically on paracoccidioidomycosis disease continue to search for new therapeutic options. Researchers continue to try to overcome the obstacles so that some of the studied molecules may be in the final stage of development in the near future and contribute to the patient's well-being, which is the end of the chain. Research is focused on the individual, who needs appropriate treatment, capable of controlling the infection and the after-effects of PCM, with few or no side effects, in a fast and effective manner. A new therapeutic option against Paracoccidioides opens new perspectives for the treatment of other mycoses.

Author Contributions: E.S.K. and M.S.S.F. idealized and structured the review. M.d.M.T. and L.F.M. wrote topic 1. E.S.K., P.d.S.B.d.M., I.R.G.C., F.A.V.R.-V., B.L.S. and A.K.R.A. wrote topic 2. A.A. wrote topic 3. E.S.K. wrote topic 4. E.S.K. and M.S.S.F. revised the manuscript. All authors have read and agreed to the published version of the manuscript.

Funding: This work was supported by the Coordenação de Aperfeiçoamento de Pessoal de Nível Superior (CAPES), Conselho Nacional de Desenvolvimento Científico e Tecnológico (CNPq) and Fundação Araucária e Fundação de Apoio à Pesquisa do Distrito Federal (FAPDF, 193.001.533/2016PRONEX/CNPq).

Institutional Review Board Statement: Not applicable.

Informed Consent Statement: Not applicable.

Data Availability Statement: No new data were created or analyzed in this study. Data sharing is not applicable to this article.

Conflicts of Interest: The authors declare no conflict of interest.

\section{References}

1. Lutz, A. A pseudococcidic mycosis localized in the mouth and observed in Brazil. A contribution to the knowledge of the American hyphoblastomycoses (in Portuguese). Brazil-Medico 1908, 22, 121-124.

2. Lacaz, C.S. Evolução dos Conhecimentos Sobre a Paracoccidioidomicose. Um Pouco de Sua História. In ParacoccidoidomicoseBlastomicose Sul-Americana; Del Negro, G., Lacaz, C.S., Fiorillo, A.M., Eds.; Sarvier-Eduso: São Paulo, Brazil, 1982.

3. Almeida, F.P. Estudos comparativos do granuloma coccidiótico nos Estados Unidos e no Brasil: Novo gênero para o parasito brasileiro. An. Fac. Med. Sao Paulo 1930, 5, 125-141.

4. Bocca, A.L.; Amaral, A.C.; Teixeira, M.M.; Sato, P.K.; Shikanai-Yasuda, M.A.; Soares Felipe, M.S. Paracoccidioidomycosis: Eco-epidemiology, taxonomy and clinical and therapeutic issues. Future Microbiol. 2013, 8, 1177-1191. [CrossRef] [PubMed]

5. Shikanai-Yasuda, M.A.; Mendes, R.P.; Colombo, A.L.; Queiroz-Telles, F.; Kono, A.S.G.; Paniago, A.M.M.; Nathan, A.; Valle, A.C.F.D.; Bagagli, E.; Benard, G.; et al. Brazilian guidelines for the clinical management of paracoccidioidomycosis. Rev. Soc. Bras. Med. Trop. 2017, 50, 715-740, Erratum in Rev. Soc. Bras. Med. Trop. 2017, 50, 879-880. [CrossRef]

6. Barbosa, W.; Daher, R.; Oliveira, A.R. Lymphatic abdominal forms of South American blastomycosis. Rev. Inst. Med. Trop. Sao Paulo 1968, 10, 12.

7. Andrade, A.L.S.S.D. Paracoccidioidomicose linfático-abdominal-Contribuição ao seu estudo. Rev. Patol. Trop. 1983, 12, 165-256.

8. Martinez, R. New Trends in Paracoccidioidomycosis Epidemiology. J. Fungi 2017, 3, 1. [CrossRef]

9. Vieira, G.D.D.; Alves, T.D.C.; Lima, S.M.D.D.; Camargo, L.M.A.; Sousa, C.M.D. Paracoccidioidomycosis in a western Brazilian Amazon State: Clinical-epidemiologic profile and spatial distribution of the disease. Rev. Soc. Bras. Med. Trop. 2014, 47, 63-68. [CrossRef]

10. Del Negro, G.M.; Benard, G.; de Assis, C.M.; Vidal, M.S.; Garcia, N.M.; Otani, C.; Shikanai-Yasuda, M.A.; Lacaz, C. Lack of reactivity of paracoccidioidomycosis sera in the double immunodiffusion test with the gp43 antigen: Report of two cases. J. Med. Vet. Mycol. 1995, 33, 113-116. [CrossRef]

11. Vidal, M.S.; Benard, G.; Brito, T.; Dantas, K.C.; Pereira, C.N.; França, F.O.; da Silva, A.M.; Martins, J.E. Atypical serological response marked by a lack of detectable anti-gp43 antibodies in a patient with disseminated paracoccidioidomycosis. J. Clin. Microbiol. 2005, 43, 3014-3016. [CrossRef]

12. Batista, J., Jr.; de Camargo, Z.P.; Fernandes, G.F.; Vicentini, A.P.; Fontes, C.J.; Hahn, R.C. Is the geographical origin of a Paracoccidioides brasiliensis isolate important for antigen production for regional diagnosis of paracoccidioidomycosis? Mycoses 2010, 53, 176-180. [CrossRef] [PubMed]

13. Molinari-Madlum, E.E.W.I.; Felipe, M.S.S.; Soares, C.M.A. Virulence of Paracoccidioides brasiliensis isolates can be correlated to groups defined by random amplified polymorphic DNA analysis. Med. Mycol. 1999, 37, 269-276. [CrossRef] [PubMed] 
14. Hahn, R.C.; Macedo, A.M.; Santos, N.L.; Resende, J.C.; Hamdan, J.S. Characterization of Paracoccidioides brasiliensis atypical isolates by random amplified polymorphic DNA analysis. Rev. Iberoam. Micol. 2002, 19, 49-51. [PubMed]

15. Hahn, R.C.; Macedo, A.M.; Fontes, C.J.; Batista, R.D.; Santos, N.L.; Hamdan, J.S. Randomly amplified polymorphic DNA as a valuable tool for epidemiological studies of Paracoccidioides brasiliensis. J. Clin. Microbiol. 2003, 41, 2849-2854. [CrossRef]

16. Taylor, J.W.; Jacobson, D.J.; Kroken, S.; Kasuga, T.; Geiser, D.M.; Hibbett, D.S.; Fisher, M.C. Phylogenetic species recognition and species concepts in fungi. Fungal Genet. Biol. 2000, 31, 21-32. [CrossRef]

17. Matute, D.R.; Sepúlveda, V.E. Fungal species boundaries in the genomics era. Fungal Genet. Biol. 2019, 131, 103249. [CrossRef]

18. Matute, D.R.; McEwen, J.G.; Puccia, R.; Montes, B.A.; San-Blas, G.; Bagagli, E.; Rauscher, J.T.; Restrepo, A.; Morais, F.; Niño-Vega, G.; et al. Cryptic speciation and recombination in the fungus Paracoccidioides brasiliensis as revealed by gene genealogies. Mol. Biol. Evol. 2006, 23, 65-73. [CrossRef]

19. Carrero, L.L.; Niño-Vega, G.; Teixeira, M.M.; Carvalho, M.J.; Soares, C.M.; Pereira, M.; Jesuino, R.S.; McEwen, J.G.; Mendoza, L.; Taylor, J.W.; et al. New Paracoccidioides brasiliensis isolate reveals unexpected genomic variability in this human pathogen. Fungal Genet. Biol. 2008, 45, 605-612. [CrossRef]

20. Da Silva, S.P.; Borges-Walmsley, M.I.; Pereira, I.S.; Soares, C.M.; Walmsley, A.R.; Felipe, M.S. Differential expression of an hsp70 gene during transition from the mycelial to the infective yeast form of the human pathogenic fungus Paracoccidioides brasiliensis. Mol. Microbiol. 1999, 31, 1039-1050. [CrossRef]

21. Teixeira, M.M.; Theodoro, R.C.; de Carvalho, M.J.; Fernandes, L.; Paes, H.C.; Hahn, R.C.; Mendoza, L.; Bagagli, E.; San-Blas, G.; Felipe, M.S. Phylogenetic analysis reveals a high level of speciation in the Paracoccidioides genus. Mol. Phylogenet. Evol. 2009, 52, 273-283. [CrossRef]

22. Teixeira, M.M.; Theodoro, R.C.; Oliveira, F.F.; Machado, G.C.; Hahn, R.C.; Bagagli, E.; San-Blas, G.; Felipe, M.S. Paracoccidioides lutzii sp. nov.: Biological and clinical implications. Med. Mycol. 2014, 52, 19-28. [CrossRef]

23. Turissini, D.A.; Gomez, O.M.; Teixeira, M.M.; McEwen, J.G.; Matute, D.R. Species boundaries in the human pathogen Paracoccidioides. Fung. Genet. Biol. 2017, 106, 9-25. [CrossRef] [PubMed]

24. Desjardins, C.A.; Champion, M.D.; Holder, J.W.; Muszewska, A.; Goldberg, J.; Bailão, A.M.; Brigido, M.M.; Ferreira, M.E.; Garcia, A.M.; Grynberg, M.; et al. Comparative genomic analysis of human fungal pathogens causing paracoccidioidomycosis. PLoS Genet. 2011, 7, e1002345. [CrossRef] [PubMed]

25. Teixeira, M.M.; Cattana, M.E.; Matute, D.R.; Muñoz, J.F.; Arechavala, A.; Isbell, K.; Schipper, R.; Santiso, G.; Tracogna, F.; de los Ángeles Sosa, M.; et al. Genomic diversity of the human pathogen Paracoccidioides across the South American continent. Fung. Genet. Biol. 2020, 140, 103395. [CrossRef]

26. Mavengere, H.; Mattox, K.; Teixeira, M.M.; Sepulveda, V.; Gomez, O.; Hernandez, O.; McEwen, J.; Matute, D.R. Paracoccidioides genomes reflect high levels of species divergence and little interspecific gene flow. mBio 2020, 11, e01999-20. [CrossRef]

27. Muñoz, J.F.; Gallo, J.E.; Misas, E.; Priest, M.; Imamovic, A.; Young, S.; Zeng, Q.; Clay, O.K.; McEwen, J.G.; Cuomo, C.A. Genome Update of the Dimorphic Human Pathogenic Fungi Causing Paracoccidioidomycosis. PLoS Negl. Trop. Dis. 2014, 8, e3348. [CrossRef]

28. Aciole Barbosa, D.; Menegidio, F.B.; Alencar, V.C.; Gonçalves, R.S.; Silva, J.F.S.; Vilas Boas, R.O.; Faustino de Maria, Y.N.L.; Jabes, D.L.; Costa de Oliveira, R.; Nunes, L.R. ParaDB: A manually curated database containing genomic annotation for the human pathogenic fungi Paracoccidioides spp. PLoS Negl. Trop. Dis. 2019, 13, e0007576. [CrossRef]

29. Goldani, L.Z.; Maia, A.L.; Sugar, A.M. Cloning and nucleotide sequence of a specific DNA fragment from Paracoccidioides brasiliensis. J. Clin. Microbiol. 1995, 33, 1652-1654. [CrossRef]

30. Cisalpino, P.S.; Puccia, R.; Yamauchi, L.M.; Cano, M.I.; da Silveira, J.F.; Travassos, L.R. Cloning, characterization, and epitope expression of the major diagnostic antigen of Paracoccidioides brasiliensis. J. Biol. Chem. 1996, 23, 4553-4560. [CrossRef]

31. Yarzabal, L.A.; Bout, D.; Naquira, F.; Fruit, J.; Andrieu, S. Identification and purification of the specific antigen of Paracoccidioides brasiliensis responsible for immunoelectrophoretic band E. Sabouraudia 1977, 15, 79-85. [CrossRef]

32. Salem-Izacc, S.M.; Jesuino, R.S.; Brito, W.A.; Pereira, M.; Felipe, M.S.; Soares, C.M. Protein synthesis patterns of Paracoccidiodes brasiliensis isolates in stage-specific forms and during cellular differentiation. J. Med. Vet. Mycol. 1997, 35, 205-211. [CrossRef] [PubMed]

33. Cunha, A.F.; Sousa, M.V.; Silva, S.P.; Jesuíno, R.S.; Soares, C.M.; Felipe, M.S. Identification, N-terminal region sequencing and similarity analysis of differentially expressed proteins in Paracoccidioides brasiliensis. Med. Mycol. 1999, 37, 115-121. [CrossRef] [PubMed]

34. Daher, B.S.; Venancio, E.J.; de Freitas, S.M.; Báo, S.N.; Vianney, P.V.; Andrade, R.V.; Dantas, A.S.; Soares, C.M.; Silva-Pereira, I.; Felipe, M.S. The highly expressed yeast gene pby20 from Paracoccidioides brasiliensis encodes a flavodoxin-like protein. Fungal Genet. Biol. 2005, 42, 434-443. [CrossRef] [PubMed]

35. Venancio, E.J.; Kyaw, C.M.; Mello, C.V.; Silva, S.P.; Soares, C.M.; Felipe, M.S.; Silva-Pereira, I. Identification of differentially expressed transcripts in the human pathogenic fungus Paracoccidioides brasiliensis by differential display. Med. Mycol. 2002, 40, 45-51. [CrossRef] [PubMed]

36. Felipe, M.S.; Andrade, R.V.; Petrofeza, S.S.; Maranhão, A.Q.; Torres, F.A.; Albuquerque, P.; Arraes, F.B.; Arruda, M.; Azevedo, M.O.; Baptista, A.J.; et al. Transcriptome characterization of the dimorphic and pathogenic fungus Paracoccidioides brasiliensis by EST analysis. Yeast 2003, 20, 263-271. [CrossRef] [PubMed] 
37. Felipe, M.S.; Andrade, R.V.; Arraes, F.B.; Nicola, A.M.; Maranhão, A.Q.; Torres, F.A.; Silva-Pereira, I.; Poças-Fonseca, M.J.; Campos, E.G.; Moraes, L.M.; et al. PbGenome Network. Transcriptional profiles of the human pathogenic fungus Paracoccidioides brasiliensis in mycelium and yeast cells. J. Biol. Chem. 2005, 280, 24706-24714. [CrossRef] [PubMed]

38. Felipe, M.S.; Torres, F.A.; Maranhão, A.Q.; Silva-Pereira, I.; Poças-Fonseca, M.J.; Campos, E.G.; Moraes, L.M.; Arraes, F.B.; Carvalho, M.J.; Andrade, R.V.; et al. Functional genome of the human pathogenic fungus Paracoccidioides brasiliensis. FEMS Immunol. Med. Microbiol. 2005, 45, 369-381. [CrossRef]

39. Andrade, R.V.; Paes, H.C.; Nicola, A.M.; de Carvalho, M.J.; Fachin, A.L.; Cardoso, R.S.; Silva, S.S.; Fernandes, L.; Silva, S.P.; Donadi, E.A.; et al. Cell organisation, sulphur metabolism and ion transport-related genes are differentially expressed in Paracoccidioides brasiliensis mycelium and yeast cells. BMC Genom. 2006, 7, 208. [CrossRef]

40. Goldman, G.H.; dos Reis Marques, E.; Duarte Ribeiro, D.C.; de Souza Bernardes, L.A.; Quiapin, A.C.; Vitorelli, P.M.; Savoldi, M.; Semighini, C.P.; de Oliveira, R.C.; Nunes, L.R.; et al. Expressed sequence tag analysis of the human pathogen Paracoccidioides brasiliensis yeast phase: Identification of putative homologues of Candida albicans virulence and pathogenicity genes. Eukaryot. Cell 2003, 2, 34-48. [CrossRef]

41. Marques, E.R.; Ferreira, M.E.; Drummond, R.D.; Felix, J.M.; Menossi, M.; Savoldi, M.; Travassos, L.R.; Puccia, R.; Batista, W.L.; Carvalho, K.C.; et al. Identification of genes preferentially expressed in the pathogenic yeast phase of Paracoccidioides brasiliensis, using suppression subtraction hybridization and differential macroarray analysis. Mol. Genet. Genom. 2004, 271, 667-677. [CrossRef]

42. Nunes, L.R.; Costa de Oliveira, R.; Leite, D.B.; da Silva, V.S.; dos Reis Marques, E.; da Silva Ferreira, M.E.; Ribeiro, D.C.; de Souza Bernardes, L.A.; Goldman, M.H.; Puccia, R.; et al. Transcriptome analysis of Paracoccidioides brasiliensis cells undergoing mycelium-to-yeast transition. Eukaryot. Cell. 2005, 4, 2115-2128. [CrossRef] [PubMed]

43. Bastos, K.P.; Bailão, A.M.; Borges, C.L.; Faria, F.P.; Felipe, M.S.; Silva, M.G.; Martins, W.S.; Fiúza, R.B.; Pereira, M.; Soares, C.M. The transcriptome analysis of early morphogenesis in Paracoccidioides brasiliensis mycelium reveals novel and induced genes potentially associated to the dimorphic process. BMC Microbiol. 2007, 7, 29. [CrossRef] [PubMed]

44. Tavares, A.H.; Silva, S.S.; Dantas, A.; Campos, E.G.; Andrade, R.V.; Maranhão, A.Q.; Brígido, M.M.; Passos-Silva, D.G.; Fachin, A.L.; Teixeira, S.M.; et al. Early transcriptional response of Paracoccidioides brasiliensis upon internalization by murine macrophages. Microbes Infect. 2007, 9, 583-590. [CrossRef] [PubMed]

45. Bailão, A.M.; Schrank, A.; Borges, C.L.; Dutra, V.; Molinari-Madlum, E.E.W.I.; Felipe, M.S.S.; Mendes-Giannini, S.M.J.; Martins, W.S.; Pereira, M.; Almeida Soares, C.M. Differential gene expression by Paracoccidioides brasiliensis in host interaction conditions: Representational difference analysis identifies candidate genes associated with fungal pathogenesis. Microbes Infect. 2006, 8, 2686-2697. [CrossRef]

46. Bailão, A.M.; Shrank, A.; Borges, C.L.; Parente, J.A.; Dutra, V.; Felipe, M.S.; Fiúza, R.B.; Pereira, M.; de Almeida Soares, C.M. The transcriptional profile of Paracoccidioides brasiliensis yeast cells is influenced by human plasma. FEMS Immunol. Med. Microbiol. 2007, 51, 43-57. [CrossRef]

47. Costa, M.; Borges, C.L.; Bailão, A.M.; Meirelles, G.V.; Mendonça, Y.A.; Dantas, S.F.I.M.; de Faria, F.P.; Felipe, M.S.S.; MolinariMadlum, E.E.W.I.; Mendes-Giannini, M.J.; et al. Transcriptome profiling of Paracoccidioides brasiliensis yeast-phase cells recovered from infected mice brings new insights into fungal response upon host interaction. Microbiology 2007, 153, 4194-4207. [CrossRef]

48. Pereira, M.; Bailão, A.M.; Parente, J.A.; Borges, C.L.; Salem-Izacc, S.M.; Soares, C.M. Preferential transcription of Paracoccidioides brasiliensis genes: Host niche and time-dependent expression. Mem. Inst. Oswaldo Cruz. 2009, 104, 486-491. [CrossRef]

49. Leal, C.V.; Montes, B.A.; Mesa, A.C.; Rua, A.L.; Corredor, M.; Restrepo, A.; McEwen, J.G. Agrobacterium tumefaciens-mediated transformation of Paracoccidioides brasiliensis. Med. Mycol. 2004, 42, 391-395. [CrossRef]

50. Soares, R.B.; Velho, T.A.; De Moraes, L.M.; Azevedo, M.O.; Soares, C.M.; Felipe, M.S. Hygromycin B-resistance phenotype acquired in Paracoccidioides brasiliensis via plasmid DNA integration. Med. Mycol. 2005, 43, 719-723. [CrossRef]

51. Almeida, A.J.; Cunha, C.; Carmona, J.A.; Sampaio-Marques, B.; Carvalho, A.; Malavazi, I.; Steensma, H.Y.; Johnson, D.I.; Leão, C.; Logarinho, E.; et al. Cdc42p controls yeast-cell shape and virulence of Paracoccidioides brasiliensis. Fungal Genet. Biol. 2009, 46, 919-926. [CrossRef]

52. Ruiz, O.H.; Gonzalez, A.; Almeida, A.J.; Tamayo, D.; Garcia, A.M.; Restrepo, A.; McEwen, J.G. Alternative oxidase mediates pathogen resistance in Paracoccidioides brasiliensis infection. PLoS Negl. Trop. Dis. 2011, 5, e1353. [CrossRef]

53. Goes, T.; Bailão, E.F.; Correa, C.R.; Bozzi, A.; Santos, L.I.; Gomes, D.A.; Soares, C.M.; Goes, A.M. New developments of RNAi in Paracoccidioides brasiliensis: Prospects for high-throughput, genome-wide, functional genomics. PLoS Negl. Trop. Dis. 2014, 8 , e3173. [CrossRef] [PubMed]

54. Torres, I.; Hernandez, O.; Tamayo, D.; Muñoz, J.F.; García, A.M.; Gómez, B.L.; Restrepo, A.; McEwen, J.G. Paracoccidioides brasiliensis PbP27 gene: Knockdown procedures and functional characterization. FEMS Yeast Res. 2014, 14, 270-280. [CrossRef]

55. Tamayo, D.; Muñoz, J.F.; Lopez, Á.; Urán, M.; Herrera, J.; Borges, C.L.; Restrepo, Á.; Soares, C.M.; Taborda, C.P.; Almeida, A.J.; et al. Identification and Analysis of the Role of Superoxide Dismutases Isoforms in the Pathogenesis of Paracoccidioides spp. PLoS Negl. Trop. Dis. 2016, 10, e0004481. [CrossRef] [PubMed]

56. Fernandes, F.F.; Oliveira, A.F.; Landgraf, T.N.; Cunha, C.; Carvalho, A.; Vendruscolo, P.E.; Gonçales, R.A.; Almeida, F.; da Silva, T.A.; Rodrigues, F.; et al. Impact of Paracoccin Gene Silencing on Paracoccidioides brasiliensis Virulence. mBio 2017, 8, e00537-17. [CrossRef] 
57. Tamayo, D.; Muñoz, J.F.; Almeida, A.J.; Puerta, J.D.; Restrepo, Á.; Cuomo, C.A.; McEwen, J.G.; Hernández, O. Paracoccidioides spp. catalases and their role in antioxidant defense against host defense responses. Fungal Genet. Biol. 2017, 100, 22-32. [CrossRef]

58. Marcos, C.M.; de Oliveira, H.C.; Assato, P.A.; de Andrade, C.R.; Fusco-Almeida, A.M.; Mendes-Giannini, M.J.S. Paracoccidioides brasiliensis 14-3-3 protein is important for virulence in a murine model. Med. Mycol. 2019, 57, 900-904. [CrossRef] [PubMed]

59. Marcos, C.M.; Tamer, G.; de Oliveira, H.C.; Assato, P.A.; Scorzoni, L.; Santos, C.T.; de Lacorte Singulani, J.; de Fátima da Silva, J.; de Almeida, R.; de Paula, E.; et al. Down-regulation of TUFM impairs host cell interaction and virulence by Paracoccidioides brasiliensis. Sci. Rep. 2019, 9, 17206. [CrossRef]

60. Oliveira, L.N.; Gonçales, R.A.; Silva, M.G.; Lima, R.M.; Tomazett, M.V.; de Curcio, J.S.; Paccez, J.D.; Cruz-Leite, V.R.M.; Rodrigues, F.; Lima, P.S.; et al. Characterization of a heme-protein responsive to hypoxia in Paracoccidioides brasiliensis. Fungal Genet. Biol. 2020, 144, 103446. [CrossRef]

61. Nett, J.E.; Andes, D.R. Antifungal Agents: Spectrum of Activity, Pharmacology, and Clinical Indications. Infect. Dis. Clin. N. Am. 2016, 30, 51-83. [CrossRef]

62. Cohen, B.E. Amphotericin B Membrane Action: Role for Two Types of Ion Channels in Eliciting Cell Survival and Lethal Effects. J. Membr. Biol. 2010, 238, 1-20. [CrossRef] [PubMed]

63. Baginski, M.; Resat, H.; Mc Cammon, J.A. Molecular Properties of Amphotericin B Membrane Channel: A Molecular Dynamics Simulation. Mol. Pharmacol. 1997, 52, 560-570. [CrossRef] [PubMed]

64. Anderson, T.M.; Clay, M.C.; Cioffi, A.G.; Diaz, K.A.; Hisao, G.S.; Tuttle, M.D.; Nieuwkoop, A.J.; Comellas, G.; Maryum, N.; Wang, S.; et al. Amphotericin forms an extramembranous and fungicidal sterol sponge. Nat. Chem. Biol. 2014, 10, 400-406. [CrossRef] [PubMed]

65. Mesa-Arango, A.C.; Trevijano-Contador, N.; Román, E.; Sánchez-Fresneda, R.; Casas, C.; Herrero, E.; Argüelles, J.C.; Pla, J.; Cuenca-Estrella, M.; Zaragoza, O. The production of reactive oxygen species is a universal action mechanism of amphotericin B against pathogenic yeasts and contributes to the fungicidal effect of this drug. Antimicrob. Agents Chemother. 2014, 58, 6627-6638. [CrossRef]

66. Shikanai-Yasuda, M.A. Paracoccidioidomycosis treatment. Rev. Inst. Med. Trop. Sao Paulo 2015, 57, 31-37. [CrossRef]

67. Queiroz-Telles, F.V.; Peçanha Pietrobom, P.M.; Rosa Júnior, M.; Baptista, R.M.; Peçanha, P.M. New Insights on Pulmonary Paracoccidioidomycosis. Semin. Respir. Crit. Care Med. 2020, 41, 53-68. [CrossRef]

68. Kato, H.; Hagihara, M.; Yamagishi, Y.; Shibata, Y.; Kato, Y.; Furui, T.; Watanabe, H.; Asai, N.; Koizumi, Y.; Mikamo, H. The evaluation of frequency of nephrotoxicity caused by liposomal amphotericin B. J. Infect. Chemother. 2018, 24, 725-728. [CrossRef]

69. Groll, A.H.; Rijnders, B.J.A.; Walsh, T.J.; Adler-Moore, J.; Lewis, R.E.; Brüggemann, R.J.M. Clinical Pharmacokinetics, Pharmacodynamics, Safety and Efficacy of Liposomal Amphotericin B. Clin. Infect. Dis. 2019, 68, S260-S274. [CrossRef]

70. Borges, S.R.; Silva, G.M.; Chambela Mda, C.; Oliveira, R.V.; Costa, R.L.; Wanke, B.; Valle, A.C. Itraconazole vs. trimethoprimsulfamethoxazole: A comparative cohort study of 200 patients with paracoccidioidomycosis. Med. Mycol. 2014, 52, 303-310. [CrossRef]

71. Shikanai-Yasuda, M.A.; Benard, G.; Higaki, Y.; Del Negro, G.M.; Hoo, S.; Vaccari, E.H.; Gryschek, R.C.; Segurado, A.A.; Barone, A.A.; Andrade, D.R. Randomized trial with itraconazole, ketoconazole and sulfadiazine in paracoccidioidomycosis. Med. Mycol. 2002, 40, 411-417. [CrossRef]

72. Menezes, V.M.; Soares, B.G.; Fontes, C.J. Drugs for treating paracoccidioidomycosis. Cochrane Database Syst Rev. 2006, 2006, CD004967. [CrossRef]

73. Groll, A.H.; Piscitelli, S.C.; Walsh, T.J. Clinical pharmacology of systemic antifungal agents: A comprehensive review of agents in clinical use, current investigational compounds, and putative targets for antifungal drug development. Adv. Pharmacol. 1998, 44, 343-500. [CrossRef] [PubMed]

74. Peyton, L.R.; Gallagher, S.; Hashemzadeh, M. Triazole antifungals: A review. Drugs Today Barc. 2015, 51, 705-718. [CrossRef] [PubMed]

75. Naranjo, M.S.; Trujillo, M.; Munera, M.I.; Restrepo, P.; Gomez, I.; Restrepo, A. Treatment of paracoccidioidomycosis with itraconazole. J. Med. Vet. Mycol. 1990, 28, 67-76. [CrossRef] [PubMed]

76. Goldani, L.Z.; Wirth, F. Animal Models and Antifungal Agents in Paracoccidioidomycosis: An Overview. Mycopathologia 2017, 182, 633-643. [CrossRef]

77. Shafiei, M.; Peyton, L.; Hashemzadeh, M.; Foroumadi, A. History of the development of antifungal azoles: A review on structures, SAR, and mechanism of action. Bioorg. Chem. 2020, 104, 104240. [CrossRef]

78. Abadio, A.K.; Kioshima, E.S.; Teixeira, M.M.; Martins, N.F.; Maigret, B.; Felipe, M.S. Comparative genomics allowed the identification of drug targets against human fungal pathogens. BMC Genom. 2011, 12, 75. [CrossRef]

79. Santos, L.A.; Grisolia, J.C.; Burger, E.; Paula, F.B.A.; Amanda Latércia Tranches Dias, A.L.T.; Malaquias, L.C.C. Virulence factors of Paracoccidioides brasiliensis as therapeutic targets: A review. Antonie Leeuwenhoek 2020, 113, 593-604. [CrossRef]

80. Rodríguez-Brito, S.; Niño-Vega, G.; San-Blas, G. Caspofungin Affects Growth of Paracoccidioides brasiliensis in Both Morphological Phases. Antimicrob. Agents Chemother. 2010, 54, 5391-5394. [CrossRef]

81. Nakai, T.; Uno, J.; Ikeda, F.; Tawara, S.; Nishimura, K.; Miyaji, M. In Vitro Antifungal Activity of Micafungin (FK463) against Dimorphic Fungi: Comparison of Yeast-Like and Mycelial Forms. Antimicrob. Agents Chemother. 2003, 47, 1376-1381. [CrossRef] 
82. Espinel-Ingroff, A. In vitro antifungal activities of anidulafungin and micafungin, licensed agents and the investigational triazole posaconazole as determined by NCCLS methods for 12,052 fungal isolates: Review of the literature. Rev. Iberoam. Micol. 2003, 20, 121-136. [PubMed]

83. Lima, S.L.; Colombo, A.L.; de Almeida Junior, J.N. Fungal Cell Wall: Emerging Antifungals and Drug Resistance. Front. Microbiol. 2019, 10, 2573. [CrossRef] [PubMed]

84. Garcia-Effron, G. Rezafungin-Mechanisms of Action, Susceptibility and Resistance: Similarities and Differences with the Other Echinocandins. J. Fungi 2020, 6, 262. [CrossRef] [PubMed]

85. Schenone, M.; Dančík, V.; Wagner, B.K.; Clemons, P.A. Target identification and mechanism of action in chemical biology and drug discovery. Nat. Chem. Biol. 2013, 9, 232-240. [CrossRef]

86. Eder, J.; Herrling, P.L. Trends in Modern Drug Discovery. Handb. Exp. Pharmacol. 2016, 232, 3-22. [CrossRef]

87. Nicola, A.M.; Albuquerque, P.; Paes, H.C.; Fernandes, L.; Costa, F.F.; Kioshima, E.S.; Abadio, A.K.R.; Bocca, A.L.; Felipe, M.S. Antifungal drugs: New insights in research \& development. Pharmacol. Ther. 2019, 195, 21-38. [CrossRef]

88. Batool, M.; Ahmad, B.; Choi, S. A Structure-Based Drug Discovery Paradigm. Int. J. Mol. Sci. 2019, 20, 2783. [CrossRef]

89. Wang, Y.; Yella, J.; Jegga, A.G. Transcriptomic Data Mining and Repurposing for Computational Drug Discovery. Methods Mol. Biol. 2019, 1903, 73-95. [CrossRef]

90. Liu, N.; Wang, C.; Su, H.; Zhang, W.; Sheng, C. Strategies in the discovery of novel antifungal scaffolds. Future Med. Chem. 2016, 8, 1435-1454. [CrossRef]

91. Gidaro, M.C.; Alcaro, S.; Secci, D.; Rivanera, D.; Mollica, A.; Agamennone, M.; Giampietro, L.; Carradori, S. Identification of new anti-Candida compounds by ligand-based pharmacophore virtual screening. J. Enzyme Inhib. Med. Chem. 2016, 31, 1703-1706. [CrossRef]

92. Xia, X. Bioinformatics and Drug Discovery. Curr. Top. Med. Chem. 2017, 17, 1709-1726. [CrossRef] [PubMed]

93. Karatzas, E.; Kolios, G.; Spyrou, G.M. An Application of Computational Drug Repurposing Based on Transcriptomic Signatures. Methods Mol. Biol. 2019, 1903, 149-177. [CrossRef] [PubMed]

94. Huo, J.; Zhao, B.; Zhang, Z.; Xing, J.; Zhang, J.; Dong, J.; Fan, Z. Structure-Based Discovery and Synthesis of Potential Transketolase Inhibitors. Molecules 2018, 23, 2116. [CrossRef] [PubMed]

95. Bakheet, T.M.; Doig, A.J. Properties and identification of human protein drug targets. Bioinformatics 2009, 25, 451-457. [CrossRef]

96. Roemer, T.; Jiang, B.; Davison, J.; Ketela, T.; Veillette, K.; Breton, A.; Tandia, F.; Linteau, A.; Sillaots, S.; Marta, C.; et al. Large-scale essential gene identification in Candida albicans and applications to antifungal drug discovery. Mol. Microbiol. 2003, 50, 167-181. [CrossRef] [PubMed]

97. Hu, W.; Sillaots, S.; Lemieux, S.; Davison, J.; Kauffman, S.; Breton, A.; Linteau, A.; Xin, C.; Bowman, J.; Becker, J.; et al. Essential gene identification and drug target prioritization in Aspergillus fumigatus. PLoS Pathog. 2007, 3, e24. [CrossRef]

98. Buurman, E.T.; Westwater, C.; Hube, B.; Brown, A.J.; Odds, F.C.; Gow, N.A. Molecular analysis of CaMnt1p, a mannosyl transferase important for adhesion and virulence of Candida albicans. Proc. Natl. Acad. Sci. USA 1998, 95, 7670-7675. [CrossRef]

99. Jensen-Pergakes, K.L.; Kennedy, M.A.; Lees, N.D.; Barbuch, R.; Koegel, C.; Bard, M. Sequencing, disruption, and characterization of the Candida albicans sterol methyltransferase (ERG6) gene: Drug susceptibility studies in erg6 mutants. Antimicrob. Agents Chemother. 1998, 42, 1160-1167. [CrossRef]

100. Perfect, J.R.; Tenor, J.L.; Miao, Y.; Brennan, R.G. Trehalose pathway as an antifungal target. Virulence 2017, 8, 143-149. [CrossRef]

101. Freitas, E.; Silva, K.S.C.; Silva, L.; Gonçales, R.A.; Neves, B.J.; Soares, C.M.A.; Pereira, M. Setting New Routes for Antifungal Drug Discovery Against Pathogenic Fungi. Curr. Pharm. Des. 2020, 26, 1509-1520. [CrossRef]

102. Yoshida, T.; Oka, S.; Masutani, H.; Nakamura, H.; Yodoi, J. The role of thioredoxin in the aging process: Involvement of oxidative stress. Antioxid Redox Signal. 2003, 5, 563-570. [CrossRef] [PubMed]

103. Holmgren, A. Thioredoxin. Annu. Rev. Biochem. 1985, 54, 237-271. [CrossRef]

104. Moore, E.C.; Reichard, P.; Thelander, L. Enzymatic synthesis of deoxyribonucleotides.v. purification and properties of thioredoxin reductase from Escherichia coli b. J. Biol.Chem. 1964, 239, 3445-3452. [CrossRef] [PubMed]

105. Williams, C.H., Jr. Mechanism and structure of thioredoxin reductase from Escherichia coli. FASEB J. 1995, 9, 1267-1276. [CrossRef] [PubMed]

106. Arnér, E.S.; Holmgren, A. Physiological functions of thioredoxin and thioredoxin reductase. Eur. J. Biochem. 2000, 267, 6102-6109. [CrossRef] [PubMed]

107. Ren, X.; Zou, L.; Lu, J.; Holmgren, A. Selenocysteine in mammalian thioredoxin reductase and application of ebselen as a therapeutic. Free Radic. Biol. Med. 2018, 127, 238-247. [CrossRef]

108. Zhang, B.; Zhang, J.; Peng, S.; Liu, R.; Li, X.; Hou, Y.; Han, X.; Fang, J. Thioredoxin reductase inhibitors: A patent review. Expert Opin. Ther. Pat. 2017, 27, 547-556. [CrossRef]

109. Lu, J.; Holmgren, A. The thioredoxin antioxidant system. Free Radic. Biol. Med. 2014, 66, 75-87. [CrossRef]

110. Saccoccia, F.; Angelucci, F.; Boumis, G.; Carotti, D.; Desiato, G.; Miele, A.E.; Bellelli, A. Thioredoxin reductase and its inhibitors. Curr. Protein Pept. Sci. 2014, 15, 621-646. [CrossRef]

111. Arnér, E.S.J. Selective Evaluation of Thioredoxin Reductase Enzymatic Activities. Methods Mol. Biol. 2018, 1661, 301-309. [CrossRef]

112. Novoselov, S.V.; Gladyshev, V.N. Non-animal origin of animal thioredoxin reductases: Implications for selenocysteine evolution and evolution of protein function through carboxy-terminal extensions. Protein Sci. 2003, 12, 372-378. [CrossRef] [PubMed] 
113. Benhar, M. Roles of mammalian glutathione peroxidase and thioredoxin reductase enzymes in the cellular response to nitrosative stress. Free Radic. Biol. Med. 2018, 127, 160-164. [CrossRef]

114. Abadio, A.K.; Kioshima, E.S.; Leroux, V.; Martins, N.F.; Maigret, B.; Felipe, M.S. Identification of new antifungal compounds targeting thioredoxin reductase of Paracoccidioides genus. PLoS ONE 2015, 10, e0142926. [CrossRef]

115. Gromer, S.; Urig, S.; Becker, K. The thioredoxin system-From science to clinic. Med. Res. Rev. 2004, 24, 40-89. [CrossRef]

116. Arnér, E.S.; Holmgren, A. The thioredoxin system in cancer. Semin. Cancer Biol. 2006, 16, 420-426. [CrossRef]

117. Sun, Q.A.; Su, D.; Novoselov, S.V.; Carlson, B.A.; Hatfield, D.L.; Gladyshev, V.N. Reaction mechanism and regulation of mammalian thioredoxin/glutathione reductase. Biochemistry 2005, 44, 14528-14537. [CrossRef]

118. Lillig, C.H.; Holmgren, A. Thioredoxin and related molecules-From biology to health and disease. Antioxid. Redox Signal. 2007, 9, 25-47. [CrossRef]

119. Pedrajas, J.R.; Kosmidou, E.; Miranda-Vizuete, A.; Gustafsson, J.A.; Wright, A.P.; Spyrou, G. Identification and functional characterization of a novel mitochondrial thioredoxin system in Saccharomyces cerevisiae. J. Biol. Chem. 1999, $274,6366-6373$. [CrossRef]

120. Trotter, E.W.; Grant, C.M. Overlapping roles of the cytoplasmic and mitochondrial redox regulatory systems in the yeast Saccharomyces cerevisiae. Eukaryot. Cell. 2005, 4, 392-400. [CrossRef]

121. Raffel, J.; Bhattacharyya, A.K.; Gallegos, A.; Cui, H.; Einspahr, J.G.; Alberts, D.S.; Powis, G. Increased expression of thioredoxin-1 in human colorectal cancer is associated with decreased patient survival. J. Lab. Clin. Med. 2003, 142, 46-51. [CrossRef]

122. Gasdaska, P.Y.; Oblong, J.E.; Cotgreave, I.A.; Powis, G. The predicted amino acid sequence of human thioredoxin is identical to that of the autocrine growth factor human adult T-cell derived factor (ADF): Thioredoxin mRNA is elevated in some human tumors. Biochim. Biophys. Acta 1994, 1218, 292-296. [CrossRef]

123. Nakamura, H.; Bai, J.; Nishinaka, Y.; Ueda, S.; Sasada, T.; Ohshio, G.; Imamura, M.; Takabayashi, A.; Yamaoka, Y.; Yodoi, J. Expression of thioredoxin and glutaredoxin, redox-regulating proteins, in pancreatic cancer. Cancer Detect. Prev. 2000, 24, 53-60. [PubMed]

124. Lim, J.Y.; Yoon, S.O.; Hong, S.W.; Kim, J.W.; Choi, S.H.; Cho, J.Y. Thioredoxin and thioredoxin-interacting protein as prognostic markers for gastric cancer recurrence. World J. Gastroenterol. 2012, 18, 5581-5588. [CrossRef] [PubMed]

125. Stafford, W.C.; Peng, X.; Olofsson, M.H.; Zhang, X.; Luci, D.K.; Lu, L.; Cheng, Q.; Trésaugues, L.; Dexheimer, T.S.; Coussens, N.P.; et al. Irreversible inhibition of cytosolic thioredoxin reductase 1 as a mechanistic basis for anticancer therapy. Sci. Transl. Med. 2018, 10, eaaf7444. [CrossRef] [PubMed]

126. Ianiri, G.; Idnurm, A. Essential gene discovery in the basidiomycete Cryptococcus neoformans for antifungal drug target prioritization. mBio 2015, 6, e02334-14. [CrossRef] [PubMed]

127. Godoy, J.S.; Kioshima, É.S.; Abadio, A.K.; Felipe, M.S.; de Freitas, S.M.; Svidzinski, T.I. Structural and functional characterization of the recombinant thioredoxin reductase from Candida albicans as a potential target for vaccine and drug design. Appl. Microbiol. Biotechnol. 2016, 100, 4015-4025. [CrossRef]

128. Capoci, I.R.G.; Sakita, K.M.; Faria, D.R.; Rodrigues-Vendramini, F.A.V.; Arita, G.S.; de Oliveira, A.G.; Felipe, M.S.; Maigret, B.; Bonfim-Mendonça, P.S.; Kioshima, E.S.; et al. Two New 1,3,4-Oxadiazoles With Effective Antifungal Activity Against Candida albicans. Front. Microbiol. 2019, 10, 2130. [CrossRef]

129. De Oliveira, F.F.M.; Paredes, V.; de Sousa, H.R.; D’Áurea Moura, Á.N.; Riasco-Palacios, J.; Casadevall, A.; Felipe, M.S.S.; Nicola, A.M. Thioredoxin Reductase 1 Is a Highly Immunogenic Cell Surface Antigen in Paracoccidioides spp., Candida albicans, and Cryptococcus neoformans. Front. Microbiol. 2020, 10, 2930. [CrossRef]

130. Faria, D.R.; Sakita, K.M.; Capoci, I.R.G.; Arita, G.S.; Rodrigues-Vendramini, F.A.V.; de Oliveira Junior, A.G.; Soares Felipe, M.S.; Bonfim de Mendonça, P.S.; Svidzinski, T.I.E.; Kioshima, E.S. Promising antifungal activity of new oxadiazole against Candida krusei. PLoS ONE 2020, 15, e0227876. [CrossRef]

131. Binder, J.; Shadkchan, Y.; Osherov, N.; Krappmann, S. The Essential Thioredoxin Reductase of the Human Pathogenic Mold Aspergillus fumigatus is a Promising Antifungal Target. Front. Microbiol. 2020, 11, 1383. [CrossRef]

132. Missall, T.A.; Lodge, J.K. Thioredoxin reductase is essential for viability in the fungal pathogen Cryptococcus neoformans. Eukaryot Cell 2005, 4, 487-489. [CrossRef] [PubMed]

133. Bravo-Chaucanés, C.P.; Abadio, A.K.R.; Kioshima, É.S.; Felipe, M.S.S.; Barbosa, J.A.R.G. Crystal structure of thioredoxin 1 from Cryptococcus neoformans at $1.8 \AA$ resolution shows unexpected plasticity of the loop preceding the catalytic site. Biochem. Biophys. Rep. 2020, 21, 100724. [CrossRef]

134. Marshall, A.C.; Kidd, S.E.; Lamont-Friedrich, S.J.; Arentz, G.; Hoffmann, P.; Coad, B.R.; Bruning, J.B. Structure, Mechanism, and Inhibition of Aspergillus fumigatus Thioredoxin Reductase. Antimicrob. Agents Chemother. 2019, 63, e02281-18. [CrossRef] [PubMed]

135. Rodrigues-Vendramini, F.A.V.; Faria, D.R.; Arita, G.S.; Capoci, I.R.G.; Sakita, K.M.; Caparroz-Assef, S.M.; Becker, T.C.A.; Bonfim-Mendonça, P.S.; Felipe, M.S.; Svidzinski, T.I.E.; et al. Antifungal activity of two oxadiazole compounds for the paracoccidioidomycosis treatment. PLoS Negl. Trop. Dis. 2019, 13, e0007441. [CrossRef]

136. Lin, X.; Li, X.; Lin, X. A Review on Applications of Computational Methods in Drug Screening and Design. Molecules 2020, 25, 1375. [CrossRef]

137. Franco, P.H.C.; Braga, S.F.P.; de Oliveira, R.B.; César, I.C. Purity determination of a new antifungal drug candidate using quantitative 1 H NMR spectroscopy: Method validation and comparison of calibration approaches. Magn. Reson. Chem. 2020, 58, 97-105. [CrossRef] 
138. Tighadouini, S.; Radi, S.; Abrigach, F.; Benabbes, R.; Eddike, D.; Tillard, M. Novel $\beta$-keto-enol Pyrazolic Compounds as Potent Antifungal Agents. Design, Synthesis, Crystal Structure, DFT, Homology Modeling, and Docking Studies. J. Chem. Inf. Model. 2019, 59, 1398-1409. [CrossRef]

139. Coitinho, J.B.; Costa, M.A.; Melo, E.M.; Morais, E.A.; de Andrade, L.G.; da Rocha, A.M.; Magalhães, M.T.Q.; Favaro, D.C.; Bleicher, L.; Pedroso, E.R.P.; et al. Structural and immunological characterization of a new nucleotidyltransferase-like antigen from Paracoccidioides brasiliensis. Mol. Immunol. 2019, 112, 151-162. [CrossRef]

140. Bagatin, M.C.; Pimentel, A.L.; Biavatti, D.C.; Basso, E.A.; Kioshima, E.S.; Seixas, F.A.V.; Gauze, G.F. Targeting the Homoserine Dehydrogenase of Paracoccidioides Species for Treatment of Systemic Fungal Infections. Antimicrob. Agents Chemother. 2017, 61, e00165-17. [CrossRef]

141. Rodrigues-Vendramini, F.A.V.; Marschalk, C.; Toplak, M.; Macheroux, P.; Bonfim-Mendonça, P.S.; Svidzinski, T.I.E.; Seixas, F.A.V.; Kioshima, E.S. Promising New Antifungal Treatment Targeting Chorismate Synthase from Paracoccidioides brasiliensis. Antimicrob. Agents Chemother. 2018, 63, e01097-18. [CrossRef]

142. Da Silva, L.S.; Barbosa, U.R.; Silva, L.D.C.; Soares, C.M.; Pereira, M.; da Silva, R.A. Identification of a new antifungal compound against isocitrate lyase of Paracoccidioides brasiliensis. Future Microbiol. 2019, 14, 1589-1606. [CrossRef] [PubMed]

143. Beautrait, A.; Leroux, V.; Chavent, M.; Ghemtio, L.; Devignes, M.D.; Smaïl-Tabbone, M.; Cai, W.; Shao, X.; Moreau, G.; Bladon, P.; et al. Multiple-step virtual screening using VSM-G: Overview and validation of fast geometrical matching enrichment. J. Mol. Model. 2008, 14, 135-148. [CrossRef]

144. Ghemtio, L.; Devignes, M.D.; Smail-Tabbone, M.; Souchet, M.; Leroux, V.; Maigret, B. Comparison of three preprocessing filters efficiency in virtual screening: Identification of new putative LXR beta regulators as a test case. J. Chem. Inf. Model. 2010, 50, 701-715. [CrossRef] [PubMed]

145. Oum, Y.H.; Kell, S.A.; Yoon, Y.; Liang, Z.; Burger, P.; Shim, H. Discovery of novel aminopiperidinyl amide CXCR4 modulators through virtual screening and rational drug design. Eur. J. Med. Chem. 2020, 201, 112479. [CrossRef] [PubMed]

146. Costa, F.G.; Neto, B.R.; Gonçalves, R.L.; da Silva, R.A.; de Oliveira, C.M.; Kato, L.; Freitas, C.S.; Giannini, M.J.; da Silva, J.F.; Soares, C.M.; et al. Alkaloids as inhibitors of malate synthase from Paracoccidioides spp.: Receptor-ligand interaction-based virtual screening and molecular docking studies, antifungal activity, and the adhesion process. Antimicrob. Agents Chemother. 2015, 59, 5581-5594. [CrossRef] [PubMed]

147. Liang, H.; Liu, H.; Kuang, Y.; Chen, L.; Ye, M.; Lai, L. Discovery of Targeted Covalent Natural Products against PLK1 by Herb-Based Screening. J. Chem. Inf. Model. 2020, 60, 4350-4358. [CrossRef] [PubMed]

148. Hughes, J.P.; Rees, S.; Kalindjian, S.B.; Philpott, K.L. Principles of early drug discovery. Br. J. Pharmacol. 2011, 162, 1239-1249. [CrossRef]

149. DiMasi, J.A.; Grabowski, H.G.; Hansen, R.W. Innovation in the pharmaceutical industry: New estimates of R\&D costs. J. Health Econ. 2016, 47, 20-33. [CrossRef]

150. Oliveira, M.A.; Discola, K.F.; Alves, S.V.; Barbosa, J.A.; Medrano, F.J.; Netto, L.E.; Guimarães, B.G. Crystallization and preliminary X-ray diffraction analysis of NADPH-dependent thioredoxin reductase I from Saccharomyces cerevisiae. Acta Crystallogr. Sect. F Struct. Biol. Cryst. Commun. 2005, 61, 387-390. [CrossRef]

151. Lennon, B.W.; Williams, C.H.; Ludwig, M.L. Twists in catalysis: Alternating conformations of Escherichia coli thioredoxin reductase. Science 2000, 289, 1190-1194. [CrossRef]

152. Kioshima, E.S.; Abadio, A.K.R.; Leurox, V.; Capoci, I.R.G.; Bonfim-Mendonça, P.S.; Felipe, M.S.; Svidzinski, T.I.E.; Maigret, B. Thioredoxin Systems as Target to New Antifungal Development. Status manuscript in preparation.

153. Bueno, P.S.A.; Rodrigues, F.A.V.; Santos, J.L.; Canduri, F.; Biavatti, D.C.; Pimentel, A.L.; Bagatin, M.C.; Kioshima, É.S.; de Freitas Gauze, G.; Seixas, F.A.V. New inhibitors of homoserine dehydrogenase from Paracoccidioides brasiliensis presenting antifungal activity. J. Mol. Model. 2019, 25, 325. [CrossRef] [PubMed]

154. Rozada, A.M.; Rodrigues, F.A.; Sampiron, E.G.; Seixas, F.A.; Basso, E.A.; Scodro, R.B.; Kioshima, É.S.; Gauze, G.F. Novel 4-methoxynaphthalene- $\mathrm{N}$-acylhydrazones as potential for paracoccidioidomycosis and tuberculosis co-infection. Future Microbiol. 2019, 14, 587-598. [CrossRef] [PubMed]

155. Rozada, A.M.F.; Rodrigues-Vendramini, F.A.V.; Gonçalves, D.S.; Rosa, F.A.; Basso, E.A.; Seixas, F.A.V.; Kioshima, É.S.; Gauze, G.F. Synthesis and antifungal activity of new hybrids pyrimido[4,5-d]pyridazinone-N-acylhydrazones. Bioorg. Med. Chem. Lett. 2020, 30, 127244. [CrossRef] [PubMed]

156. Silva, P.A.; Abadio, A.K.R.; Kioshima, E.S.; Leroux, V.; Martins, N.F.; Nahum, V.H.; Mora-Montes, H.M.; Maigret, B.; Felipe, M.S.S Inhibitors of $\alpha-1,2-$ mannosyltransferase as Promising Antifungal Activity against The Invasive Fungal Infections Agents. Status manuscript in preparation.

157. Salci, T.P.; Negri, M.; Abadio, A.K.R.; Bonfim-Mendonça, P.S.; Capoci, I.R.G.; Caparroz-Assef, S.M.; Donati, L.; Felipe, M.S.S.; Kioshima, E.S.; Svidzinski, T.I.E. A new small molecule KRE2 inhibitor against invasive Candida parapsilosis infection. Future Microbiol. 2017, 12, 1283-1295. [CrossRef] [PubMed]

158. Silva, L.C.; Neves, B.J.; Gomes, M.N.; Melo-Filho, C.C.; Soares, C.M.; Andrade, C.H.; Pereira, M. Computer-aided identification of novel anti-paracoccidioidomycosis compounds. Future Microbiol. 2018, 13, 1523-1535. [CrossRef] [PubMed]

159. Ashburn, T.T.; Thor, K.B. Drug repositioning: Identifying and developing new uses for existing drugs. Nat. Rev. Drug Discov. 2004, 3, 673-683. [CrossRef]

160. Butts, A.; Krysan, D.J. Antifungal drug discovery: Something old and something new. PLoS Pathog. 2012, 8, e1002870. [CrossRef] 
161. Katragkou, A.; Roilides, E.; Walsh, T.J. Can repurposing of existing drugs provide more effective therapies for invasive fungal infections? Expert Opin. Pharmacother. 2016, 17, 1179-1182. [CrossRef]

162. FDA approvals for the first 6 months of 2014. Nat. Rev. Drug. Discov. 2014, 13, 565. [CrossRef]

163. Zerbini, L.F.; Bhasin, M.K.; de Vasconcellos, J.F.; Paccez, J.D.; Gu, X.; Kung, A.L.; Libermann, T.A. Computational repositioning and preclinical validation of pentamidine for renal cell cancer. Mol. Cancer Ther. 2014, 13, 1929-1941. [CrossRef]

164. Wiederhold, N.P.; Patterson, T.F.; Srinivasan, A.; Chaturvedi, A.K.; Fothergill, A.W.; Wormley, F.L.; Ramasubramanian, A.K.; Lopez-Ribot, J.L. Repurposing auranofin as an antifungal: In vitro activity against a variety of medically important fungi. Virulence 2017, 8, 138-142. [CrossRef] [PubMed]

165. Ekins, S.; Williams, A.J.; Krasowski, M.D.; Freundlich, J.S. In silico repositioning of approved drugs for rare and neglected diseases. Drug Discov. Today 2011, 16, 298-310. [CrossRef] [PubMed]

166. Kim, K.; Zilbermintz, L.; Martchenko, M. Repurposing FDA approved drugs against the human fungal pathogen, Candida albicans. Ann. Clin. Microbiol. Antimicrob. 2015, 14, 32. [CrossRef] [PubMed]

167. Nixon, G.L.; McEntee, L.; Johnson, A.; Farrington, N.; Whalley, S.; Livermore, J.; Natal, C.; Washbourn, G.; Bibby, J.; Berry, N.; et al Repurposing and Reformulation of the Antiparasitic Agent Flubendazole for Treatment of Cryptococcal Meningoencephalitis, a Neglected Fungal Disease. Antimicrob. Agents Chemother. 2018, 62, e01909-17. [CrossRef]

168. Capoci, I.R.G.; Faria, D.R.; Sakita, K.M.; Rodrigues-Vendramini, F.A.V.; Bonfim-Mendonça, P.S.; Becker, T.C.A.; Kioshima, É.S.; Svidzinski, T.I.E.; Maigret, B. Repurposing approach identifies new treatment options for invasive fungal disease. Bioorganic Chem. 2019, 84, 87-97. [CrossRef]

169. De Oliveira, A.A.; Neves, B.J.; do Silva, L.C.; de Soares, C.M.A.; Andrade, C.H.; Pereira, M. Drug Repurposing for Paracoccidioidomycosis Through a Computational Chemogenomics Framework. Front. Microbiol. 2019, 10, 1301. [CrossRef]

170. Caffrey, C.R.; Rohwer, A.; Oellien, F.; Marhöfer, R.J.; Braschi, S.; Oliveira, G.; McKerrow, J.H.; Selzer, P.M. A comparative chemogenomics strategy to predict potential drug targets in the metazoan pathogen, Schistosoma mansoni. PLoS ONE 2009, 4, e4413. [CrossRef]

171. Bredel, M.; Jacoby, E. Chemogenomics: An emerging strategy for rapid target and drug discovery. Nat. Rev. Genet. 2004, 5, 262-275. [CrossRef]

172. Neves, B.J.; Braga, R.C.; Bezerra, J.C.; Cravo, P.V.; Andrade, C.H. In silico repositioning-chemogenomics strategy identifies new drugs with potential activity against multiple life stages of Schistosoma mansoni. PLoS Negl. Trop. Dis. 2015, 9, e3435. [CrossRef]

173. Arif, T.; Bhosale, J.D.; Kumar, N.; Mandal, T.K.; Bendre, R.S.; Lavekar, G.S.; Dabur, R. Natural products-antifungal agents derived from plants. J. Asian Nat. Prod. Res. 2009, 11, 621-638. [CrossRef] [PubMed]

174. San-Blas, G.; Mariño, L.; San-Blas, F.; Apitz-Castro, R. Effect of ajoene on dimorphism of Paracoccidioides brasiliensis. J. Med. Vet. Mycol. 1993, 31, 133-141. [CrossRef] [PubMed]

175. San-Blas, G.; Urbina, J.A.; Marchán, E.; Contreras, L.M.; Sorais, F.; San-Blas, F. Inhibition of Paracoccidioides brasiliensis by ajoene is associated with blockade of phosphatidylcholine biosynthesis. Microbiology 1997, 143, 1583-1586. [CrossRef]

176. Maluf, M.L.; Takahachi, G.; Svidzinski, T.I.; Xander, P.; Apitz-Castro, R.; Bersani-Amado, C.A.; Cuman, R.K. Antifungal activity of ajoene on experimental murine paracoccidioidomycosis. Rev. Iberoam. Micol. 2008, 25, 163-166. [CrossRef]

177. Thomaz, L.; Apitz-Castro, R.; Marques, A.F.; Travassos, L.R.; Taborda, C.P. Experimental paracoccidioidomycosis: Alternative therapy with ajoene, compound from Allium sativum, associated with sulfamethoxazole/trimethoprim. Med. Mycol. 2008, 46, 113-118. [CrossRef] [PubMed]

178. Santos, G.D.; Ferri, P.H.; Santos, S.C.; Bao, S.N.; Soares, C.M.; Pereira, M. Oenothein B inhibits the expression of PbFKS1 transcript and induces morphological changes in Paracoccidioides brasiliensis. Med. Mycol. 2007, 45, 609-618. [CrossRef] [PubMed]

179. Zambuzzi-Carvalho, P.F.; Tomazett, P.K.; Santos, S.C.; Ferri, P.H.; Borges, C.L.; Martins, W.S.; Soares, C.M.A.; Pereira, M. Transcriptional profile of Paracoccidioides induced by oenothein $\mathrm{B}$, a potential antifungal agent from the Brazilian Cerrado plant Eugenia uniflora. BMC Microbiol. 2013, 13, 227. [CrossRef] [PubMed]

180. De Freitas, C.S.; Kato, L.; de Oliveira, C.M.; Queiroz, L.H., Jr.; Santana, M.J.; Schuquel, I.T.; Delprete, P.G.; da Silva, R.A.; Quintino, G.O.; da Silva Neto, B.R.; et al. $\beta$-Carboline alkaloids from Galianthe ramosa inhibit malate synthase from Paracoccidioides spp. Planta Med. 2014, 80, 1746-1752. [CrossRef] [PubMed]

181. Zambuzzi-Carvalho, P.F.; Cruz, A.H.; Santos-Silva, L.K.; Goes, A.M.; Soares, C.M.; Pereira, M. The malate synthase of Paracoccidioides brasiliensis $\mathrm{Pb} 01$ is required in the glyoxylate cycle and in the allantoin degradation pathway. Med. Mycol. 2009, 47, 734-744. [CrossRef]

182. De Oliveira, K.M.; da Silva Neto, B.R.; Parente, J.A.; da Silva, R.A.; Quintino, G.O.; Voltan., A.R.; Mendes-Giannini, M.J.S.; Soares, C.M.A.; Pereira, M. Intermolecular interactions of the malate synthase of Paracoccidioides spp. BMC Microbiol. 2013, 13, 107. [CrossRef]

183. Prado, R.S.; Alves, R.J.; Oliveira, C.M.; Kato, L.; Silva, R.A.; Quintino, G.O.; do Desterro Cunha, S.; Soares, C.M.A.; Pereira, M. Inhibition of Paracoccidioides lutzii $\mathrm{Pb} 01$ isocitrate lyase by the natural compound argentilactone and its semi-synthetic derivatives. PLoS ONE 2014, 9, e94832. [CrossRef]

184. Cruz, A.H.; Brock, M.; Zambuzzi-Carvalho, P.F.; Santos-Silva, L.K.; Troian, R.F.; Góes, A.M.; Soares, C.M.; Pereira, M. Phosphorylation is the major mechanism regulating isocitrate lyase activity in Paracoccidioides brasiliensis yeast cells. FEBS J. 2011, 278, 2318-2332. [CrossRef] [PubMed] 
185. Do Carmo Silva, L.; Tamayo Ossa, D.P.; Castro, S.V.; Bringel Pires, L.; Alves de Oliveira, C.M.; Conceição da Silva, C.; Coelho, N.P.; Bailão, A.M.; Parente-Rocha, J.A.; Soares, C.M.; et al. Transcriptome Profile of the Response of Paracoccidioides spp. to a Camphene Thiosemicarbazide Derivative. PLoS ONE 2015, 10, e0130703. [CrossRef] [PubMed]

186. Borba, J.V.V.B.; Tauhata, S.B.F.; Oliveira, C.M.A.; Ferreira Marques, M.; Bailão, A.M.; Soares, C.M.A.; Pereira, M. Chemoproteomic identification of molecular targets of antifungal prototypes, thiosemicarbazide and a camphene derivative of thiosemicarbazide, in Paracoccidioides brasiliensis. PLoS ONE 2018, 13, e0201948. [CrossRef] [PubMed]

187. Amaral, A.C.; Marques, A.F.; Muñoz, J.E.; Bocca, A.L.; Simioni, A.R.; Tedesco, A.C.; Morais, P.C.; Travassos, L.R.; Taborda, C.P.; Felipe, M.S. Poly(lactic acid-glycolic acid) nanoparticles markedly improve immunological protection provided by peptide P10 against murine paracoccidioidomycosis. Br. J. Pharmacol. 2010, 159, 1126-1132. [CrossRef] [PubMed]

188. Santos Junior, S.R.; Silva, F.K.L.; Dias, L.S.; Souza, A.C.O.; Araujo, M.V.; Silva, L.B.R.; Travassos, L.R.; Amaral, A.C.; Taborda, C.P. Intranasal Vaccine Using P10 Peptide Complexed within Chitosan Polymeric Nanoparticles as Experimental Therapy for Paracoccidioidomycosis in Murine Model. J. Fungi 2020, 6, 160. [CrossRef] [PubMed]

189. Ribeiro, A.M.; Souza, A.C.; Amaral, A.C.; Vasconcelos, N.M.; Jeronimo, M.S.; Carneiro, F.P.; Faccioli, L.H.; Felipe, M.S.; Silva, C.L.; Bocca, A.L. Nanobiotechnological approaches to delivery of DNA vaccine against fungal infection. J. Biomed. Nanotechnol. 2013, 9 , 221-230. [CrossRef]

190. Jannuzzi, G.P.; Souza, N.A.; Françoso, K.S.; Pereira, R.H.; Santos, R.P.; Kaihami, G.H.; Almeida, J.R.F.; Batista, W.L.; Amaral, A.C.; Maranhão, A.Q.; et al. Therapeutic treatment with scFv-PLGA nanoparticles decreases pulmonary fungal load in a murine of paracoccidioidomycosis. Microbes Infect. 2018, 20, 48-56. [CrossRef]

191. Amaral, A.C.; Bocca, A.L.; Ribeiro, A.M.; Nunes, J.; Peixoto, D.L.; Simioni, A.R.; Primo, F.L.; Lacava, Z.G.; Bentes, R.; Titze-de-Almeida, R.; et al. Amphotericin B in poly(lactic-co-glycolic acid) (PLGA) and dimercaptosuccinic acid (DMSA) nanoparticles against paracoccidioidomycosis. J. Antimicrob. Chemother. 2009, 63, 526-533. [CrossRef]

192. Saldanha, C.A.; Garcia, M.P.; Iocca, D.C.; Rebelo, L.G.; Souza, A.C.; Bocca, A.L.; Almeida Santos, M.F.; Morais, P.C.; Azevedo, R.B. Antifungal Activity of Amphotericin B Conjugated to Nanosized Magnetite in the Treatment of Paracoccidioidomycosis. PLoS Negl. Trop. Dis. 2016, 10, e0004754. [CrossRef]

193. Cunha-Azevedo, E.P.; Py-Daniel, K.R.; Siqueira-Moura, M.P.; Bocca, A.L.; Felipe, M.S.S.; Tedesco, A.C.; Junior, O.R.P.; Lucci, C.M.; Azevedo, R.B. In vivo evaluation of the efficacy, toxicity and biodistribution of PLGA-DMSA nanoparticles loaded with itraconazole for treatment of paracoccidioidomycosis. J. Drug Deliv. Sci. Technol. 2018, 45, 135-141. [CrossRef]

194. Souza, A.C.; Amaral, A.C. Antifungal Therapy for Systemic Mycosis and the Nanobiotechnology Era: Improving Efficacy, Biodistribution and Toxicity. Front. Microbiol. 2017, 8, 336. [CrossRef] [PubMed]

195. Farjadian, F.; Ghasemi, A.; Gohari, O.; Roointan, A.; Karimi, M.; Hamblin, M.R. Nanopharmaceuticals and nanomedicines currently on the market: Challenges and opportunities. Nanomed. Lond. 2019, 14, 93-126. [CrossRef] [PubMed]

196. Amaral, A.C.; Felipe, M.S. Nanobiotechnology: An efficient approach to drug delivery of unstable biomolecules. Curr. Protein Pept. Sci. 2013, 14, 588-594. [CrossRef] [PubMed]

197. Detsi, A.; Kavetsou, E.; Kostopoulou, I.; Pitterou, I.; Pontillo, A.R.N.; Tzani, A.; Christodoulou, P.; Siliachli, A.; Zoumpoulakis, P. Nanosystems for the Encapsulation of Natural Products: The Case of Chitosan Biopolymer as a Matrix. Pharmaceutics 2020, 12, 669. [CrossRef] [PubMed]

198. Garcia, M.P.; Parca, R.M.; Chaves, S.B.; Silva, L.P.; Santos, A.D.; Lacava, Z.G.M.; Morais, P.C.; Azevedo, R.B. Morphological analysis of mice's lung after treatment with magnetite-based magnetic fluid stabilized with DMSA. J. Magn. Magn. Mater. 2005, 293, 277-282. [CrossRef]

199. Yilma, S.; Liu, N.; Samoylov, A.; Lo, T.; Brinker, C.J.; Vodyanoy, V. Amphotericin B channels in phospholipid membrane-coated nanoporous silicon surfaces: Implications for photovoltaic driving of ions across membranes. Biosens. Bioelectron. 2007, 22, 1605-1611. [CrossRef]

200. Souza, A.C.; Nascimento, A.L.; de Vasconcelos, N.M.; Jerônimo, M.S.; Siqueira, I.M.; Santos, L.; Cintra, D.O.; Fuscaldi, L.L.; Pires Júnior, O.R.; Titze-de-Almeida, R.; et al. Activity and in vivo tracking of Amphotericin B loaded PLGA nanoparticles. Eur. J. Med. Chem. 2015, 95, 267-276. [CrossRef]

201. Suneet, K.; Sridhar, S.; Agiwal, P.; Sridhar, M.S.; Sanyal, K.; Jain, S. Magnetic hyperthermia adjunctive therapy for fungi: In vitro studies against Candida albicans. Int. J. Hyperth. 2019, 36, 545-553. [CrossRef]

202. Feng, Q.; Liu, Y.; Huang, J.; Chen, K.; Huang, J.; Xiao, K. Uptake, distribution, clearance, and toxicity of iron oxide nanoparticles with different sizes and coatings. Sci. Rep. 2018, 8, 2082. [CrossRef]

203. Denning, D.W.; Bromley, M.J. Infectious Disease. How to bolster the antifungal pipeline. Science 2015, 347, 1414-1416. [CrossRef]

204. Perfect, J.R. "Is there an emerging need for new antifungals?". Expert. Opin. Emerg. Drugs 2016, 21, 129-131. [CrossRef] [PubMed]

205. Gustafson, H.H.; Holt-Casper, D.; Grainger, D.W.; Ghandehari, H. Nanoparticle uptake: The phagocyte problem. Nano Today 2015, 10, 487-510. [CrossRef] [PubMed]

206. Bandeira, A.C.; de Oliveira Matos, A.; Evangelista, B.S.; da Silva, S.M.; Nagib, P.R.A.; de Moraes Crespo, A.; Amaral, A.C. Is it possible to track intracellular chitosan nanoparticles using magnetic nanoparticles as contrast agent? Bioorg. Med. Chem. 2019, 27, 2637-2643. [CrossRef] [PubMed]

207. Puccia, R.; Schenkman, S.; Gorin, P.A.J.; Travassos, L.R. Exocellular components of Paracoccidoides brasiliensis: Identification of a specific antigen. Infect. Immun. 1986, 53, 199-206. [CrossRef] [PubMed] 